\title{
LA REALIZACIÓN SUSTITUTIVA DE LA SUBASTA JUDICIAL EN EL Anteproyecto de Código Procesal Civil chileno. REFLEXIONES A PARTIR DE SU REgULACIÓN EN LA LEY DE ENJUICIAMIENTO CiVIL ESPAÑOLA
}

\author{
José Bonet NAVARro*
}

Resumen: A propósito de la presentación del Anteproyecto de Código Procesal Civil, en este trabajo el autor pretende contribuir a salvar algunas de las imperfecciones $u$ omisiones en la materia relativa a la regulación de la realización de bienes o derechos embargados, y que vienen a sustituir a otros medio tradicionales de realización como la subasta judicial o incluso la llamada prenda pretoria; a la luz de la doctrina, de la experiencia y Derecho español.

Palabras Clave: Realización de bienes - Apremio - Convenio Audiencia.

\section{The substitutive execution of the Judicative Auction in the draft bill of the Chilean Civil Procedural Code. Thoughts on the Regulation of the Spanish Civil Procedure Statute}

ABSTRACT: Speaking of the presentation of the civil procedural draft bill, the author intends to contribute to cover some of the imperfections and omissions related to the regulation of attachment goods or rights, that come to substitute other traditional means of execution such as the judicative auction or even the so called judicative antichresis; in the light of doctrine, experience and the Spanish Law.

KEY wORDs: Execution of goods - Enforcement - Agreement - Hearing.

SUMARIO: I. Introducción. II. Los nuevos modos de realización de bienes en el Anteproyecto de Código Procesal Civil como relevante novedad. III. Las reglas

Profesor Titular de Derecho Procesal, Universitat de València (Estudi General), EsPaña. Magistrado Suplente de la Audiencia Provincial de Valencia. Correo electrónico: jose.bonet@uv.es Fecha de recepción: 30 de enero de 2008.

Fecha de aceptación: 30 de marzo de 2008. 
del procedimiento de apremio en el ACPC chileno en comparación con la LEC española: 1. convenio de realización. 2. realización a através de persona o "institución" especializada. IV. Reflexiones sobre el convenio de realización tal y como ba sido propuesto en el art. 459 ACPC: 1. La audiencia. 1.1. Sus requisitos y las excesivas dudas que plantea por la imprevisión en muchos puntos. 1.2. Principales caracteres de la audiencia o comparecencia. 2. El convenio de realización. 2.1. Las excesivas dificultades para su aprobación. 2.2. Efecto suspensivo de la aprobación. 2.3. Cumplimiento o incumplimiento del acuerdo. V. Reflexiones sobre la realización a través de persona o institución especializada conforme se propone en el art. 460 ACPC: 1. Exigencias generales para que una persona o entidad determinada asuman este sistema de realización. 1.1. Requisitos en la persona o en la entidad: conocimiento del mercado en que se compran y venden los bienes y "requisitos legalmente exigidos". 1.2. Prestación de caución por personas o determinadas entidades especializadas. 1.3. Determinación de las condiciones en que deba efectuarse la realización. 2. Exigencias, limites y cautelas particulares para la adopción de este sistema de realización. 2.1. Comparecencia. 2.2. Necesario acuerdo cualificado en ciertos casos para que se autorice la enajenación. 3. Cumplimiento o incumplimiento del encargo de realización. 3.1. Consumación de la realización. 3.2. Incumplimiento. VI. Reflexión última de carácter general.

\section{INTRODUCCIÓN}

En la presentación que abre el Anteproyecto de Código Procesal Civil (en adelante ACPC) entregado al Ministerio de Justicia en fechas recientes, se reconoce la magnífica labor de las muchas personas que han participado en su redacción, si bien a continuación reconoce estar "seguro que las imperfecciones y omisiones de los redactores del anteproyecto serán salvadas posteriormente, dado que no exista obra perfecta que salga de la mano del ser bumano o comisión alguna".

En este trabajo principalmente pretendo contribuir a salvar algunas de las "imperfecciones" u omisiones que en mi opinión concurren en los extensos arts. 459 y 460 ACPC, reguladores de la realización de bienes o derechos embargados, y que vienen a sustituir a otros medios tradicionales de realización como la subasta judicial o incluso la llamada "prenda pretoria".

El sometimiento al debate doctrinal y de los colectivos jurídicos implicados que sufrieron los textos preparatorios y previos a la vigente Ley 1/2000 de Enjuiciamiento Civil española (en adelante LEC) puede valorarse como altamente positivo en el contexto de la labor de mejora producida en la lenta gestación de su texto definitivo. Todas las aportaciones sirvieron como mínimo para llamar la atención sobre algunos de los aspectos y puntos mejorables, y enriquecieron en general su redacción, hasta el punto de que desde el texto inicial del Borrador de Anteproyecto de LEC, pasan- 
do por el Anteproyecto y Proyecto de LEC, hasta el definitivo publicado en el Boletín Oficial del Estado núm. 7, de 8 de enero de 2000, la redacción difiere sustancialmente en muchos de sus puntos. Así y todo, esta forma de elaboración no ha evitado que a fecha de hoy su texto haya sufrido ya repetidas modificaciones, incluso algunas de cierto calado ${ }^{1}$.

Si el modelo que se contiene en este Anteproyecto en relación con la realización de bienes o derechos embargados llega a convertirse en una realidad legislativa, sin duda supondrá una verdadera revolución en el procedimiento de apremio, puesto que no solamente se incorporan figuras novedosas para el actual Código de Procedimiento Civil chileno, sino que estas nada menos que sustituyen a la tradicional subasta judicial.

Aparte de esto, la regulación concreta del convenio de realización en el art. 459 ACPC así como de la enajenación a través de persona o "institución" especializada en el 460 del mismo, sin perjuicio de algunas diferencias formales, de adecuación y sistemática y hasta de fondo, se inspiran claramente en los correlativos arts. 640 y 641 LEC española. Los problemas de interpretación y consiguiente aplicación que plantean son en ambos casos similares cuantitativa y cualitativamente. Por tal motivo, considero que convendría aprovechar la experiencia doctrinal y jurisprudencial española al menos para intentar completar y aclarar algunos de sus extremos y sobre todo intentando evitar errores similares.

Por lo expuesto, salvando las distancias culturales y de tradición jurídica que sin duda han de ser debidamente atendidas por el legislador, estimo que merece alguna atención este punto, siempre en un intento de contribuir de algún modo en mejorar esta regulación con tanta trascendencia práctica y hasta económica.

\section{Los nuevos modos de realización de bienes en el ANTepro- yecto de Código Procesal Civil como relevante novedad}

El ACPC, no obstante las puntuales afinidades casi miméticas en ocasiones con algunos ordenamientos procesales de nuevo cuño y muy particularmente con la LEC, ha introducido importantes novedades si lo comparamos con el todavía vigente Código de Procedimiento Civil chileno y hasta con la propia LEC de la que en principio se nutre ${ }^{2}$.

1 Entre otras reformas menores, las dadas por Ley $15 / 2005$ de 8 de julio, que introduce novedades en materia de separación y divorcio; o por Ley 23/2003, de 10 julio, de Garantías en la Venta de Bienes de Consumo, que aporta importantes modificaciones sobre todo nuevas especialidades en el juicio de desahucio por falta de pago, generalmente tendentes a acercar su regulación a la derogada de la LEC de 1881.

2 Para una visión panorámica del proceso de ejecución español, véase Fernández Seijo, José María "La ejecución en la nueva Ley de Enjuiciamiento Civil". En http://perso.wanadoo.es/ilandin/textos/librotercero.btml 
Un buen ejemplo lo encontramos en la materia de la que ahora voy a ocuparme y que representa una de las novedades más significativas introducidas en el ACPC en el contexto del proceso de ejecución. La principal novedad, calificable como de "extraordinaria" si por último llegara a convertirse en texto legal aplicable, es que lo que en la LEC no son más que medios "alternativos" 3 , en el ACPC se configuran como "sustitutivos" de la subasta judicial, que desaparece como tal en el ordenamiento procesal chileno.

Sin duda los tradicionales métodos de realización, y particularmente la subasta judicial, han venido demostrando una eficacia más bien insatisfactoria ${ }^{4}$. Probablemente por tal motivo, el legislador español introdujo como importante novedad dos medios alternativos a la subasta judicial como son la realización mediante convenio judicialmente aprobado, que tiene carácter preferente (art. $636.2 \mathrm{LEC})^{5}$, y el que se produce a través de persona o entidad especializada. Asimismo, intenta potenciar la llamada "administración para el pago" como modo alternativo y no necesariamente subsidiario de realización, admisible cuando lo aconsejen las características del bien y así lo solicite el ejecutante en cualquier momento del procedimiento de apremio (arts. 676 a 680 LEC).

En el ACPC chileno se va mucho más lejos, y los medios de realización que introduce la LEC como alternativos a la subasta judicial aquí son configurados como medios sustitutivos de la misma. En ese sentido, salvo que se trate de bienes y derechos que por su naturaleza no requieran realización y puedan ser entregados directamente al ejecutante (dinero, saldos en cuentas corrientes, divisas y similares) o que por su naturaleza requiera

Específicamente sobre los medios alternativos a la subasta, además de otras obras que se citarán en este trabajo, puede verse Bonet NAVArro, José (2002) "Alternativas a la subasta en el proceso civil de ejecución", Revista Internauta de Práctica Jurídica, núm. 10, en bttp://www. wi.es/ ripj/10alt.botm

Así lo ha constatado la doctrina española en repetidas ocasiones, por ejemplo, Franco Arias, Just (2000) "Del convenio de realización". En Lorca (Director) Comentarios a la nueva Ley de Enjuiciamiento Civil, III, Valladolid: Lex Nova, p. 3273. Casero Linares, Luis (2001) "Procedimiento de apremio". Garbería (Coordinador) Los procesos civiles. Comentarios a la Ley de Enjuiciamiento Civil, con formularios y jurisprudencia, 5. Barcelona: Bosch, p. 29. RoBLEDo VILlaR, Antonio (2001) "La realización forzosa de bienes en la Ley de Enjuiciamiento Civil a través de los medios alternativos a la subasta judicial". Robledo y otros. Estudios jurídicos, secretarios judiciales, VII-2001. Madrid, Centro de Estudios Jurídicos de la Administración de Justicia, p. 361. Montero Aroca, Juan (2001) El nuevo proceso civil. Ley 1/2000 (con Gómez, Montón y Barona). Valencia: Tirant lo Blanch, $2^{\mathrm{a}}$ ed., p. 785, quien contundentemente dice que la experiencia "demostró que esa subasta era un modo de malvender los bienes".

Que se trate de medios alternativos de realización no se contradice con que el convenio judicialmente aprobado pueda ser preferente. En el ámbito del proceso civil, incluido el proceso de ejecución, regido por el principio dispositivo, es consecuente que se dé preferencia a la voluntad para la iniciativa de la actividad procesal. Por eso el art. 636.2 LEC habla de que " $a$ falta de convenio de realización, la enajenación de los bienes embargados se llevará a cabo por...". Ahora bien, se trata de medios alternativos en la medida en que la subasta procederá cuando no se opte por alguno de los otros medios o, elegidos, no sea acordado por falta de presupuestos según el régimen que analizamos en este trabajo. 
de una realización a través de mercados específicos básicamente a través de corredor de bolsa (acciones y otras formas de participación), el art. 456 ACPC es rotundo cuando nos indica que los bienes y derechos se realizarán "en la forma convenida entre las partes e interesados y aprobada por el tribunal, con arreglo a lo previsto en esta Ley. A falta de convenio de realización, la enajenación de los bienes embargados se llevará a cabo por medio de persona o entidad especializada". Y en eso queda todo. Por tanto, los métodos tradicionales de realización y sobre todo la subasta judicial (arts. 488 y ss. Código de Procedimiento Civil) y hasta incluso la llamada "prenda pretoria"6 $(500.3$, 501,503 a 508 del mismo CPC) quedan de ese modo excluidos y sustituidos por el convenio y por la realización por medio de persona o entidad especializada.

Por lo que se refiere a la adjudicación para pago, regulada en los arts. 499.1, 500.1 del vigente CPC, aunque no contiene una previsión específica en el Anteproyecto, no parece que quepa descartarla. Si repasamos el texto del ACPC encontraremos referencias directas a la misma, al menos en los arts. 479 y 486 ACPC que se refieren a la "adjudicación de bienes embargados al ejecutante" como dies ad quem para la finalización de las tercerías llamadas respectivamente en los mismos como "de prelación" y "de pago"; y sobre todo en el art. 463 ACPC que, en relación con la inscripción de la adquisición en el Registro de la Propiedad, considera título bastante el testimonio expedido por el tribunal comprensivo del auto de la adjudicación al acreedor.

\section{LAS REGLAS DEL PROCEDIMIENTO DE APREMIO EN EL ACPC CHILENO EN COMPARACIÓN CON LA LEC ESPAÑOLA}

El procedimiento para proceder a la ejecución, según el art. 222 ACPC, se regulará por "las reglas del procedimiento de apremio". Al margen de la entrega directa al ejecutante cuando se trate de bienes y derechos que lo permiten (art. $454 \mathrm{ACPC}$ ) y de bienes que por ser acciones y otras formas de participación han de ser realizados en mercados específicos y en general por Corredor de Bolsa (art. 455 ACPC), este procedimiento no será otro más que el previsto en los arts. 459 y 460.

$\mathrm{Si}$ bien en el punto anterior resaltaba la trascendente novedad del sistema de realización forzosa en el ACPC, no puede decirse lo mismo cuando atendemos a su regulación concreta y la comparamos con los correspondientes preceptos que disciplinan el convenio de realización y la realización por persona o entidad especializada en los arts. 640 y 641 LEC. En efecto, no obstante algunas diferencias de forma y de fondo, encontraremos en am- 
bas redacciones más que significativas coincidencias, incluso lingüísticas. Veamos sus textos (con negrita y cursiva resalto las diferencias).

\section{CONVENIO DE REALIZACIÓN}

En este caso las coincidencias son palmarias y las diferencias de mero matiz ${ }^{7}$.

\section{ACPC}

El ejecutante, el ejecutado y quien acredite interés actual y directo en la ejecución podrán pedir al tribunal que convoque una audiencia con la finalidad de convenir el modo de realización más eficaz de los bienes hipotecados, pignorados o embargados, frente a los que se dirige la ejecución.

Si el ejecutante se mostrare conforme con la comparecencia y el tribunal no encontrare motivos razonables para denegarla, la acordará mediante providencia, sin suspensión de la ejecución, convocando a las partes y a quienes conste en el proceso que pudieren estar interesados.

En la comparecencia, a la que podrán concurrir otras personas, por invitación de ejecutante o ejecutado, los asistentes podrán proponer cualquier forma de realización de los bienes sujetos a la ejecución y presentar a persona que, consignando o afianzando, se ofrezca a adquirir dichos bienes por un precio previsiblemente superior al que pudiera lograrse mediante la subasta judicial. También cabrá proponer otras formas de satisfacción del derecho del ejecutante.

\section{LEC}

1. El ejecutante, el ejecutado y quien acredite interés directo en la ejecución podrán pedir al tribunal que convoque una comparecencia con la finalidad de convenir el modo de realización más eficaz de los bienes hipotecados, pignorados o embargados, frente a los que se dirige la ejecución.

2. Si el ejecutante se mostrare conforme con la comparecencia y el tribunal no encontrare motivos razonables para denegarla, la acordará mediante providencia, sin suspensión de la ejecución, convocando a las partes y a quienes conste en el proceso que pudieren estar interesados.

En la comparecencia, a la que podrán concurrir otras personas, por invitación de ejecutante o ejecutado, los asistentes podrán proponer cualquier forma de realización de los bienes sujetos a la ejecución y presentar a persona que, consignando o afianzando, se ofrezca a adquirir dichos bienes por un precio previsiblemente superior al que pudiera lograrse mediante la subasta judicial. También cabrá proponer otras formas de satisfacción del derecho del ejecutante. 
Si se llegare a un acuerdo entre ejecutante y ejecutado, que no pueda causar perjuicio para tercero, lo aprobará el tribunal mediante resolución y suspenderá la ejecución respecto del bien o bienes objeto del acuerdo. También aprobará el acuerdo, con el mismo efecto suspensivo, si incluyere la conformidad de los sujetos, distintos de ejecutante y ejecutado, a quienes afectare.

Cuando el convenio se refiera a bienes susceptibles de inscripción registral será necesaria, para su aprobación, la conformidad de los acreedores y terceros poseedores que hubieran inscrito o anotado sus derechos en el Registro correspondiente con posterioridad al gravamen que se ejecuta.

Cuando se acreditare el cumplimiento del acuerdo, se sobreseerá la ejecución respecto del bien o bienes a que se refiriese. Si el acuerdo no se cumpliere dentro del plazo pactado o, por cualquier causa, no se lograse la satisfacción del ejecutante en los términos convenidos, podrá éste pedir que se alce la suspensión de la ejecución y se proceda a la subasta, en la forma prevista en esta ley.

Si no se lograse el acuerdo a que se refiere el inciso tercero de este artículo, la comparecencia para intentarlo podrá repetirse, en las condiciones previstas en los dos primeros incisos de este artículo, cuando las circunstancias del caso lo aconsejen, a juicio del tribunal, para la mejor realización de los bienes.
3. Si se llegare a un acuerdo entre ejecutante y ejecutado, que no pueda causar perjuicio para tercero cuyos derechos proteja esta Ley, lo aprobará el tribunal mediante auto y suspenderá la ejecución respecto del bien o bienes objeto del acuerdo. También aprobará el acuerdo, con el mismo efecto suspensivo, si incluyere la conformidad de los sujetos, distintos de ejecutante y ejecutado, a quienes afectare.

Cuando el convenio se refiera a bienes susceptibles de inscripción registral será necesaria, para su aprobación, la conformidad de los acreedores y terceros poseedores que hubieran inscrito o anotado sus derechos en el Registro correspondiente con posterioridad al gravamen que se ejecuta.

4. Cuando se acreditare el cumplimiento del acuerdo, se sobreseerá la ejecución respecto del bien o bienes a que se refiriese. Si el acuerdo no se cumpliere dentro del plazo pactado o, por cualquier causa, no se lograse la satisfacción del ejecutante en los términos convenidos, podrá éste pedir que se alce la suspensión de la ejecución y se proceda a la subasta, en la forma prevista en esta Ley.

5. Si no se lograse el acuerdo a que se refiere el apartado tercero de este artículo, la comparecencia para intentarlo podrá repetirse, en las condiciones previstas en los dos primeros apartados de este artículo, cuando las circunstancias del caso lo aconsejen, a juicio del tribunal, para la mejor realización de los bienes. 
La simple lectura de ambos textos nos permite llegar a la conclusión inicial de que las similitudes son más que anecdóticas. Y si con las similitudes no fuera ya suficiente, hay un dato que permite afirmar que el art. 459 ACPC es una importación del art. 640 LEC: en el párrafo tercero de aquel se traslada literalmente el contenido del art. 640.2.II LEC, disponiendo que los asistentes a la comparecencia puedan proponer formas de realización y presentar a persona que consignando o afianzando, se ofrezca a adquirir dichos bienes "por un precio previsiblemente superior al que pudiera lograrse mediante la subasta judicial". Y precisamente la referencia a esta subasta judicial, que una vez sustituida por el propio convenio y no como mera alternativa de la misma carece de lógica y de congruencia, viene a dejar patente que el citado art. 459 ACPC es una copia deficientemente adaptada del art. 640 LEC.

Y en la misma línea, resulta significativo que en su inciso sexto reproduzca los términos de la LEC y hable de que "si el acuerdo no se cumpliere... no se lograse la satisfacción del ejecutante... podrá éste pedir que se alce la suspensión de la ejecución y se proceda a la subasta, en la forma prevista en esta ley". Desde luego no se refiere a una "subasta" judicial, carente de atención expresa en el articulado del ACPC, sino a la realización por persona o entidad especializada en los términos del siguiente art. 460 del mismo ACPC. Y no parece que ese precepto suponga necesariamente la realización de subasta alguna, cuando omite tal denominación y prevé que se "determinarán las condiciones en que debe efectuarse la realización".

En cualquier caso, la regla general es la identidad entre ambos preceptos, y solamente cabe reputar como excepcionales las diferencias. Y en mi opinión, salvo algún matiz, tales diferencias son meramente lingüísticas:

- No se numeran ciertos párrafos en "apartados" como hace la LEC.

- Se califica como "audiencia" (art. 459.I ACPC), lo que en la LEC se llama "comparecencia". Cuestión que se revela de mero matiz puesto que en los dos incisos siguientes y en el último del mismo precepto, el ACPC habla igualmente de "comparecencia".

- Se refiere al término genérico "resolución" (art. 459.IV ACPC), en lugar del más específico "auto" de la LEC.

- Se habla de "inciso" o "incisos", en lugar de "apartado" o "apartados" como la LEC.

Incluso puede en principio entenderse como meramente lingüística también la exigencia de que el interés sea "actual y directo", a diferencia de lo que previene la LEC que se limita a imponer que el interés sea "directo". Parece claro que no siendo actual el interés, este habrá dejado de ser un verdadero interés, y desde este punto de vista, la matización sería solo "decorativa". No obstante, se trata de un calificativo aclaratorio que podría encontrar algún sentido en el contexto de la sociedad chilena, quizá 
como prevención ante la posiciones de quienes pudieran mantener ciertas reivindicaciones ancestrales. Desde ese punto de vista, la referencia a la actualidad del interés no sería casual ni decorativa, sino que estaría pensada para excluir a quienes pretendiesen sostener determinados derechos como los de ciertos colectivos indígenas.

Por otra parte, junto a la necesidad de que no se pueda causar perjuicios para tercero, en el texto del ACPC se elimina la precisión de que se trate de terceros "cuyos derechos proteja esta Ley". Ciertamente la matización es innecesaria y hasta perturbadora, puesto que si se trata de terceros han de estar protegidos por alguna ley, y si bien principalmente será la contenida en el Código Procesal Civil, no necesariamente ha de ser así. Desde esa perspectiva, considero que ha de valorarse positivamente la supresión de ese matiz innecesario y en cierto modo perturbador por el que el tercero haya de tener derechos protegidos en el mismo texto en que se recoge la norma.

\section{Realización a através de persona o "institución” especializada}

Todavía manteniendo la general identidad, en este caso las diferencias son algo más acusadas ${ }^{8}$ que en el precepto anterior:

\section{ACPC}

A falta de acuerdo entre ejecutante y ejecutado, el tribunal acordará mediante resolución, que el bien lo realice una persona o institución especializada y conocedora del mercado en que se compran y venden esos bienes y en quien concurran los requisitos legalmente exigidos para operar en el mercado de que se trate.

También podrá acordar el tribunal, cuando así se solicite en los términos previstos en el inciso anterior, que el bien se enajene por medio de entidad especializada pública o privada. Cuando así se disponga, la enajenación se acomodará a las reglas y usos de la casa

\section{LEC}

\section{A petición del ejecutante o} del ejecutado con consentimiento del ejecutante y cuando las características del bien embargado así lo aconsejen, el tribunal podrá acordar, mediante providencia, que el bien lo realice persona especializada y conocedora del mercado en que se compran y venden esos bienes y en quien concurran los requisitos legalmente exigidos para operar en el mercado de que se trate.

También podrá acordar el tribunal, cuando así se solicite en los términos previstos en el párrafo anterior, que el bien se enajene por medio de entidad especializada pública o privada. Cuando así se disponga, la enajenación se acomodará a las reglas y usos de la casa o entidad que subasta 
o entidad que subaste o enajene, siempre que no sean incompatibles con el fin de la ejecución y con la adecuada protección de los intereses de ejecutante y ejecutado.

En los casos del inciso anterior, la persona o entidad especializada deberá prestar caución en la cuantía que el tribunal determine para responder del cumplimiento del encargo. No se exigirá caución cuando la realización se encomiende a una entidad registrada en la Corporación del Poder Judicial, la que deberá cumplir para ello con los requisitos que se contemplen en el Reglamento que debe regular esta materia.

La realización se encomendará a la persona o entidad designada en la solicitud, siempre que reúna los requisitos legalmente exigidos.

En la misma resolución se determinarán las condiciones en que deba efectuarse la realización, de conformidad con lo que las partes hubiesen acordado al respecto. A falta de acuerdo, los bienes no podrán ser enajenados por precio inferior del avalúo.

No obstante lo dispuesto en el inciso anterior, cuando los bienes a realizar sean inmuebles, la determinación de la persona o entidad a la que vaya a confiarse la realización y la de las condiciones en que ésta deba efectuarse, será realizada previa comparecencia a la que serán convocadas las partes y quienes conste en el proceso que pudieran estar interesados. El tribunal resolverá por medio de pro- o enajene, siempre que no sean incompatibles con el fin de la ejecución y con la adecuada protección de los intereses de ejecutante y ejecutado.

2. En los casos del apartado anterior, la persona o entidad especializada deberá prestar caución en la cuantía que el tribunal determine para responder del cumplimiento del encargo. No se exigirá caución cuando la realización se encomiende a una entidad pública.

3. La realización se encomendará a la persona o entidad designada en la solicitud, siempre que reúna los requisitos legalmente exigidos. En la misma resolución se determinarán las condiciones en que deba efectuarse la realización, de conformidad con lo que las partes hubiesen acordado al respecto. A falta de acuerdo, los bienes no podrán ser enajenados por precio inferior al 50 por 100 del avalúo.

No obstante lo dispuesto en el párrafo anterior, cuando los bienes a realizar sean inmuebles, la determinación de la persona o entidad a la que vaya a confiarse la realización y la de las condiciones en que ésta deba efectuarse, será realizada previa comparecencia a la que serán conyocadas las partes y quienes conste en el proceso que pudieran estar interesados. El tribunal resolverá por medio de providencia lo que estime procedente, a la vista de las manifestaciones de quienes asistan a la comparecencia, 
videncia lo que estime procedente, a la vista de las manifestaciones de quienes asistan a la comparecencia, pero no podrá autorizar que la enajenación se realice por precio inferior al valor de tasación que se haya dado al inmueble con arreglo a lo previsto en el artículo 458 , salvo que conste el acuerdo de las partes y de todos los interesados, hayan asistido o no a la comparecencia.

Tan pronto como se consume la realización de los bienes se procederá por la persona o entidad correspondiente a ingresar en la cuenta corriente del tribunal la cantidad obtenida, descontando los gastos efectuados y lo que corresponda a aquellas por su intervención. El tribunal deberá aprobar la operación o, en su caso, solicitar las justificaciones oportunas sobre la realización y sus circunstancias.

\section{Cuando, transcurridos seis} meses desde el encargo, la realización no se hubiera llevado a cabo, el tribunal dictará auto revocando el encargo, salvo que se justifique por la persona o entidad a la que se hubiera efectuado éste que la realización no ha sido posible en el plazo indicado por motivos que no le sean imputables y que, por haber desaparecido ya dichos motivos o por ser previsible su pronta desaparición, el encargo podrá cumplimentarse dentro del plazo que se ofrezca y que no podrá exceder de los siguientes seis meses.

Transcurrido este último pla- pero no podrá autorizar que la enajenación se realice por precio inferior al 70 por 100 del valor que se haya dado al inmueble con arreglo a lo previsto en el artículo 666, salvo que conste el acuerdo de las partes y de todos los interesados, hayan asistido o no a la comparecencia.

\section{Tan pronto como se consume} la realización de los bienes se procederá por la persona o entidad correspondiente a ingresar en la Cuenta de Depósitos y Consignaciones la cantidad obtenida, descontando los gastos efectuados y lo que corresponda a aquellas por su intervención. El tribunal deberá aprobar la operación o, en su caso, solicitar las justificaciones oportunas sobre la realización y sus circunstancias. Aprobada la operación, se devolverá la caución que bubiese prestado la persona o entidad a la que se baya encomendado la realización.

5. Cuando, transcurridos seis meses desde el encargo, la realización no se hubiera llevado a cabo, el tribunal dictará auto revocando el encargo, salvo que se justifique por la persona o entidad a la que se hubiera efectuado éste que la realización no ha sido posible en el plazo indicado por motivos que no le sean imputables y que, por haber desaparecido ya dichos motivos o por ser previsible su pronta desaparición, el encargo podrá cumplimentarse dentro del plazo que se ofrezca y que no podrá exceder de los siguientes seis meses. Transcurrido este último plazo sin que se hubiere cumplido el encargo, se revocará definitivamente éste. 
zo sin que se hubiere cumplido el encargo, se revocará definitivamente éste.
Revocado el encargo, la caución se aplicará a los fines de la ejecución, salvo que la persona o entidad que la bubiese prestado acredite que la realización del bien no ha sido posible por causas que no le sean imputables.

De nuevo la simple comparación de ambos textos nos permite observar que el ACPC se ha "inspirado" claramente en la LEC. No obstante, diversamente a lo que ocurría con el precepto anterior, encontramos diferencias no solamente formales o lingüísticas sino también de algún mayor calado de fondo.

En cuanto a las diferencias estrictamente formales:

- Separa en dos párrafos lo que en la LEC es el art. 641.3, concretamente entre "...los requisitos legalmente exigidos" y "En la misma resolución se determinarán...".

- También del mismo modo al visto antes, se refiere al término genérico "resolución" (art. 460.I ACPC), en lugar del más específico "providencia" de la LEC.

Cuestión esta última que pronto se revela claramente como menor y de mera redacción cuando a continuación, en el inciso sexto, el mismo art. 460 ACPC dispone que cuando los bienes a realizar sean inmuebles, tras la comparecencia realizada para la determinación de la persona o entidad y de las condiciones en que deberá efectuarse la realización, el tribunal resolverá "por medio de providencia" a la vista de las manifestaciones de quienes asistan a dicha comparecencia.

- Al igual que en el precepto anterior no se numeran ciertos párrafos en "apartados" como hace la LEC, y se habla de "inciso", en lugar de "apartado".

Este cambio terminológico en ocasiones deja patente que se ha realizado de forma automática y con cierta falta de sincronización. Concretamente, cuando en el inciso tercero se sustituye la palabra "apartado" del art. 641.2.I LEC por "inciso", y se mantiene el resto de la frase "en los casos del inciso anterior...", se incurre en una clara falta de sincronización en la remisión, por resultar parcialmente limitada. Si la referencia en la LEC al "apartado" en singular es lógica puesto que este se integra por dos párrafos y a ambos remite, cuando en el ACPC se eliminan los apartados y quedan dos incisos, al hablar del "inciso" anterior manteniéndolo en singular como en la LEC y no en plural, parece que el inciso tercero se refiere solamente al inciso anterior 
cuando debería hacer referencia a los dos anteriores, pues ambos formaban el "apartado" anterior en la LEC.

Hasta esta misma falta de sincronización se observa en algunas ocasiones en las que, por el contrario, se mantiene la misma redacción. Así puede observarse cuando en el inciso cuarto se afirma que "La realización se encomendará a la persona o entidad designada en la solicitud...". Y si nos fijamos, esta solicitud es necesaria y concurrente en el sistema del art. 641 LEC, pero en los términos del art. 460 ACPC no tiene sentido alguno, puesto que este medio procederá no cuando se solicite sino "a falta de acuerdo".

- El art. 460.I ACPC matiza que se realizará por "una" persona y añade "o institución especializada", variando de ese modo la redacción de la LEC que en el párrafo primero del art. 641.1 se refiere exclusivamente a persona especializada y en su párrafo segundo del mismo a la "entidad especializada, pública o privada".

En mi opinión, es más que dudoso que estos matices mejoren la redacción de la LEC. Y no solamente por una cuestión de sistemática sino incluso por razones de fondo. En primer lugar, si el ACPC en su inciso primero pretende un pronunciamiento general sobre la realización tanto por persona como por "institución especializada", no tiene ningún sentido que traslade literalmente el texto del párrafo segundo del art. 641.1 LEC, señalando que "también podrá acordar el tribunal... que el bien se enajene por medio de entidad especializada privada o pública" puesto que antes ya nos ha dicho que podía hacerlo. Pero es más, en segundo lugar, el texto así trasladado sin más se presenta incongruente con lo que pretende regular su punto primero. Si el art. 460 ACPC nos dice en su inciso primero que "a falta de acuerdo entre ejecutante y ejecutado, el tribunal acordará mediante resolución...", no parece consecuente que luego copie el texto de la LEC y nos diga en su inciso segundo que "también podrá acordar el tribunal, cuando así se solicite en los términos previstos en el inciso anterior..." pues nos acaba de decir que aunque no se solicite, el tribunal lo acordará.

Asimismo, hay algunas diferencias propias y necesarias en la adaptación del contenido del art. 641 LEC en el contexto del Anteproyecto y de la propia organización institucional en Chile:

- Se dispone que se ingresará la cantidad obtenida "en la cuenta corriente del tribunal" (art. 460.VII ACPC) cuando en derecho español se habla de la "Cuenta de Depósitos y Consignaciones" (art. 641.4 LEC), que viene en definitiva a ser básicamente lo mismo pero con otros matices y denominación.

- Como no podía ser de otro modo, la coherencia interna de cada texto hace que el inciso sexto del art. $460 \mathrm{ACPC}$ remita al art. $458 \mathrm{del}$ 
mismo en relación con el valor de tasación de los inmuebles, en lugar de al equivalente art. 666 de la LEC como hace el correlativo art. 641.3.II de la misma LEC a los efectos de la valoración de inmuebles para la subasta.

Por último, concurren diferencias más de fondo:

La primera y principal deriva del hecho apuntado antes de que la realización por persona o institución especializada, al contrario de lo que ocurre en derecho español, no es una alternativa solamente admisible previa petición del ejecutante o del ejecutado con consentimiento del ejecutante y además limitada a que las características del bien embargado "así lo aconsejen", sino que, muy al contrario y en coherencia además con el art. $456 \mathrm{ACPC}$, se regula como el medio de realización que en general se aplicará a falta de acuerdo entre ejecutante y ejecutado. En tal caso, la realización por persona o institución especializada y conocedora del mercado se acordará mediante "resolución". Esta es, precisamente, la característica que dota a la propuesta del Anteproyecto de una extraordinaria novedad en relación tanto con el Código de Procedimiento Civil todavía vigente en Chile y hasta respecto del texto de la LEC española, a pesar de que en el mismo sin duda se inspira.

Como corolario a la previsión anterior, la exención de la prestación de caución, que en el art, 641.2 LEC se limita a las entidades públicas, en el art. 460.3 ACPC alcanza a toda "entidad registrada en la Corporación del Poder Judicial, la que deberá cumplir para ello con los requisitos que se contemplen en el Reglamento que debe regular esta materia".

En cierto modo también como consecuencia del carácter general de este medio a falta de convenio y a diferencia de lo previsto en la LEC, los límites mínimos para la enajenación son mucho más severos en el ACPC. Cuando en la LEC a falta de acuerdo de las condiciones en que deba efectuarse la realización el "tribunal" no autorizará que la enajenación se realice por precio inferior al 50 o al $70 \%$ del valor de tasación según se trate de muebles o inmuebles respectivamente, en el ACPC solamente se autorizará cuando el precio supere el valor de tasación. Ello sin perjuicio de que tanto en el ACPC como en la LEC, en caso de inmuebles podrá autorizarse por precio inferior cuando "conste el acuerdo de las partes y de todos los interesados, hayan asistido o no a la comparecencia".

Por último, en el texto del ACPC se elimina toda referencia al destinto de la caución eventualmente prestada una vez finalizado el encargo de realización, sea una vez aprobada la operación, con su consiguiente devolución; o sea al revocarse el encargo, en cuyo caso dice la LEC que "la caución se aplicará a los fines de la ejecución, salvo que la persona o entidad que la hubiese prestado acredite que la realización del bien no ha sido posible por causas que no le sean imputables". 
La eliminación de estas previsiones específicas puede obedecer a una diversidad de causas, por ejemplo: que la mayoría (o todas, en la práctica) de las personas o entidades habrán de encontrarse registradas en la Corporación del Poder Judicial, de modo que estando exentas de caución, harían innecesaria la previsión; o también, el menos en parte a que, siendo el sistema general a falta de convenio, difícilmente va a revocarse el encargo. Sin embargo, aunque en la práctica las posibilidades de prever un destino de la caución se reduce, eventualmente se darán los presupuestos para que se tenga que decidir sobre los mismos, de modo que la imprevisión legislativa no parece justificarse en razón técnica alguna.

\section{REFLEXIONES SOBRE EL CONVENIO DE REALIZACIÓN TAL Y COMO HA SIDO PROPUESTO EN EL ART. 459 ACPC}

Ejecutante o ejecutado, así como incluso cualquiera que acredite un interés actual y directo en la ejecución, separada o conjuntamente tienen la posibilidad de pedir al juez que convoque una comparecencia con la finalidad de convenir el modo de realización más eficaz de los bienes hipotecados, pignorados o sencillamente embargados frente a los que se dirige

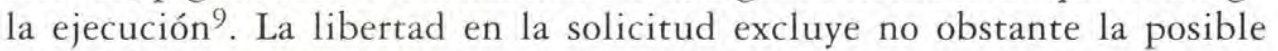
adopción de oficio, lo que se presenta como lógico pues de lo contrario resultaría contradictorio con la propia naturaleza del convenio que se pretende.

El objeto del convenio es articular el modo de realización más eficaz de los bienes trabados frente a los que se dirige la ejecución. La propia idea de realización, y especialmente la más eficaz, evoca fundamentalmente la conversión del bien objeto de realización a dinero ${ }^{10}$. Sin duda la realización es la principal finalidad de la realización y, por ello, lo que pretende lograr el art. 459 ACPC. No obstante lo anterior, cabe preguntarse si el objeto del convenio, denominado como "convenio de realización judicialmente aprobado", podría poner su énfasis no solamente en la realización sino más bien en la idea de "satisfacción" del ejecutante que, en definitiva, es donde se dirige toda ejecución ${ }^{11}$. En otros términos, sí cabría mediante

9 Desde una perspectiva prácrica, como viene a señalar Robledo Villar, la existencia de negociaciones con visos de prosperar son muy convenientes para el éxito de la comparecencia. Sin embargo, entiendo que no es descartable en todo caso que tales negociaciones se intenten como objeto de la misma comparecencia, pues en absoluto la existencia previa de las mismas es requisito para que sea acordada. RoBLEdo VILLAR (2001) 367.

10 Recoge esta idea general, en similares términos, Banacloche Palao, Julio (2001) "Del convenio de realización", Comentarios a la Ley de Enjuiciamiento Civil (con De la Oliva, DíezPicazo y Vegas). Madrid: Civitas, p. 1111, si bien a continuación matiza (p. 1113) que está "dirigida a determinar el mejor modo de obtener la satisfacción de todos los implicados".

11 Conforme el art. 415 ACPC, "la ejecución forzosa solo terminará con la completa satisfacción 
convenio adoptar medidas como administración para pago, adjudicación directa al ejecutante, dación en pago, pago por tercero, permuta de bienes, servidumbre mediante pago, arrendamiento, etc. En mi opinión, no solamente resultaría conveniente esta interpretación en cuanto ofrece mayores posibilidades de culminación con éxito la ejecución y en todo caso más márgenes de libertad, sino que además el propio art. 459.III ACPC lo viene a reconocer cuando prevé que "también cabrá proponer otras formas de satisfacción del derecho del ejecutante". De ese modo, cabría interpretar razonablemente que el convenio de "realización" tuviera como objeto formas de satisfacción que consistan muy indirectamente, o sencillamente que no consistan, en la conversión a dinero de un bien ${ }^{12}$. Lo relevante, en definitiva, sería que el ejecutante quedara "satisfecho" con lo convenido.

del acreedor ejecutante". Y hasta el mismo art. 459.VI ACPC habla de la "satisfacción del ejecutante en los términos convenidos".

Así lo ha hecho la doctrina española mayoritaria en relación con el equivalente art. 640 LEC. Entre otros, Cordón Moreno, Faustino (2001a) "Del convenio de realización". En Cordón, Armenta, Muerza y Tapia (coor.). Comentarios a la Ley de Enjuiciamiento Civil, II. Elcano: Aranzadi, p. 414, afirma que "el convenio que se persigue puede tener cualquier contenido admisible en Derecho, ya que se trata de conseguir a través de él el modo de realización más eficaz atendidos todos los derechos e intereses en juego en el proceso de ejecución". Sin embargo, este mismo autor y obra señala más adelante (p. 415) que es discutible que puedan cobijarse formas de satisfacción que no supongan una realización en sentido estricto (adjudicación, administración o enajenación). Para Hoya Coromina, José (2000) "Del convenio de realización". En Fernández-Ballesteros, Rifá y Valls (Coordinación) Comentarios a la nueva Ley de Enjuiciamiento Civil. Artículos 556 al 827. Barcelona: Iurgium editores, p. 2997, resulta evidente que queda al margen del convenio los acuerdos extrajudiciales y las transacciones que acreedor y ejecutado puedan concluir quedando al margen los intereses y derechos de terceros. Ahora bien, el mismo autor y obra, pp. 2998-9 señala -opinión en la que me sumo- que "la libertad de propuestas se extiende a la posibilidad de establecer cualquier medio de satisfacción del derecho del ejecutante, incluso sin la liquidación del propio bien o bienes objeto de ejecución... el objeto del convenio no solo se centrará en la realización del bien o bienes objeto de ejecución, sino que la norma permite cualesquiera otra formas de satisfacción del derecho del ejecutante que no se concreten en la realización de los bienes. En consecuencia, es posible convenir cualquier medio que satisfaga el derecho, desde la dación en pago hasta la novación de la deuda". Y en ese sentido, Montero Aroca (2001) 786, afirma que la comparecencia es "la manera de llegar a un convenio sobre cualquier forma de realización e, incluso, de cualquier forma de satisfacción del ejecutante". VEGAS TORRES, Jaime (2000) Derecho Procesal Civil. Ejecución forzosa. Procesos especiales (con De la Oliva y Díez-Picazo). Madrid: Editorial Centro de Estudios Ramón Areces, pp. 261-2, considera que la alusión a "otras formas de satisfacción del derecho del ejecutante" ampara que se hagan propuestas que no comporten, en sentido estricto, "realización" de los bienes, como facilidades para realizar el pago a plazos, quitas parciales, etc. En similar sentido PEDraz Penalva, Ernesto / Moral. Moro, María José (2001) "El procedimiento de apremio". En Gimeno (Director) Proceso Civil Práctico, VIII-1. Madrid: La Ley, p. I-63, citan como ejemplos de otras formas de colmar el interés del ejecutante, entre otras, la constitución de una servidumbre de paso, de luces o vistas. Robledo VILLAR (2001) 376-7, apunta que nada impide que su utilización permita otros contenidos como una administración paga pago, adjudicación directa al ejecutante, dación en pago, pago por tercero, permuta de bienes, servidumbre mediante pago, arrendamiento, ofrecimiento y realización a cuenta del crédito impagado así como toda aquella que pueda producir satisfacción. 


\section{La audiencia}

A la audiencia (llamada en los incisos siguientes también "comparecencia") serán convocadas las partes y quienes consten en el proceso como interesados. Se acordará mediante providencia y sin suspensión de la ejecución, cuando el ejecutante se mostrare conforme y siempre que el juez no encuentre motivos razonables para denegarla.

\subsection{Sus requisitos y las excesivas dudas que plantea por la imprevi- sión en muchos puntos}

El art. 459 ACPC deja claro que para que sea acordada la audiencia o comparecencia se requiere petición, sea del ejecutante, del ejecutado o de quien acredite interés directo y actual en la ejecución. Entre estos últimos podrá incluirse, entre otros, los acreedores posteriores, que reembargaron o embargaron el sobrante, ocupantes y, en general, todo aquel que tenga un derecho real que deba ser extinguido. Pero nos mantiene en la incertidumbre sobre la forma que habrá de tener dicha solicitud y el momento en que se formulará.

Desde luego habrá de ser solicitada estando pendiente el proceso de ejecución, pues no de otro modo se acordará "sin suspensión de la ejecución"; y más concretamente, salvo que sea innecesario el embargo (bienes hipotecados o pignorados), habiéndose trabado el bien o derecho correspondiente. Pero no estaría de más que el precepto matizara si el avalúo del bien ha de haberse igualmente producido, cuestión que planteó algún debate doctrinal con ocasión de la interpretación de art. $640 \mathrm{LEC}^{13}$. El dies ad quem para la solicitud parece claro que será hasta el momento mismo en que se realice el bien conforme previene el siguiente precepto, aunque no queda suficientemente claro exactamente qué momento concreto será el que hará inviable esta comparecencia,

13 Para BANAClOChE (2001) 1113, "parece razonable" que se haya realizado ya la valoración del bien. En el mismo sentido, Vegas Torres (2000) 261, argumentando que el avalúo es actuación común, concluye que cuando la comparecencia se celebre las actuaciones del avalúo "deberían haber finalizado". En esa línea también Cordón Moreno (2001) 414-5. Y con similar sentido, Moreno Catena, Víctor (2000) "La ejecución forzosa". En Moreno y Cortés (Coordinadores) La nueva Ley de Enjuiciamiento Civil, IV. Madrid: Tecnos, p. 214, considera que en los casos de enajenación "sería oportuno tener previamente establecido el valor de tasación del bien; es decir, que se habría de ordenar de inmediato el avalúo, antes de la comparecencia". Por el contrario, HOYA COROMINA (2000) 3001, parte de que "al convenio podría haberse llegado sin que se hubiera verificado el avalúo" para defender que, en caso de incumplimiento ulterior del convenio, la valoración acordada sustituiría el avalúo en la subasta ulterior. En mi opinión, son reconciliables ambas posturas. La valoración será necesaria, pero podrá ser sustituida por la acordada por las partes en el propio convenio (art. 637 LEC in fine). Más ecléctico, Robledo Villar (2001) 372, señala que el tiempo idóneo comienza con el avalúo, pero "aún sin negar una instancia en un momento anterior". 
máxime cuando se pretenda que la misma no tenga carácter suspensivo de la ejecución.

Asimismo, no estaría de más que igualmente se considerara la conveniencia de matizar que la petición hubiera de motivarse expresando las ventajas concretas, por más eficaz, de la forma de realización solicitada frente a la alternativa de realización por persona o institución especializada, sobre todo conveniente cuando se solicite por personas distintas al ejecutante sin conversaciones previas entre las partes.

Por otra parte, no queda suficientemente claro si la necesaria conformidad del ejecutante habrá de ser expresa o si bastará con que se manifieste tácitamente. Parece que siendo la finalidad de la convocatoria convenir un presumiblemente mejor sistema de realización y no teniendo efecto suspensivo, cabe interpretar que será admisible la forma tácita. No resulta razonable y sí muy formalista que solicitando la audiencia el mismo ejecutante se le exija a su vez una conformidad expresa, implícita y necesaria en la propia solicitud. Y con la misma lógica, si la solicitud la formulara el ejecutado o algún tercero, bastaría igualmente para entender que se da tal conformidad con la no oposición por el mismo ejecutante ${ }^{14}$. Sin embargo, en este último caso, requeriría que se articulara algún tipo de trámite previo por el que se diera traslado de la petición al ejecutante a efectos de que muestre bien su conformidad expresa o tácita, bien su disconformidad expresa.

Parece que los motivos que concurrirían para admitir una conformidad tácita por el ejecutante, no justificaría en ningún caso que la comparecencia pudiera ser admitida no obstante constar la inconformidad expresa del ejecutante a su celebración, sin embargo, la imprevisión legislativa permite sustentar igualmente opiniones diametralmente opuestas ${ }^{15}$.

Tampoco fija el precepto un plazo para la realización de la convocatoria. Aunque ante la imprevisión algún autor ha entendido que deberá ser fijado por el tribunal y ser "necesariamente muy corto" 16 , igualmente se hace precisa alguna mención al respecto en la que se concrete si habrá de celebrarse inmediatamente o fijando el plazo en que habrá de producirse.

Por lo demás, solamente se exige que no concurran motivos "razonables" para denegarla. Al margen de la falta de conformidad por el ejecutante, no se hace otra referencia más concreta, por tal motivo se hace difícil conocer a qué motivos "razonables” podrá referirse exactamente ${ }^{17}$,

14 En ese sentido, Franco Arias (2000) 3273. No obstante muestra su disconformidad HoYa Coromina (2000) 2997, cuando se refiere a la "exigencia por la norma de la expresa aceptación por parte del ejecutante".

15 Por ejemplo, mantiene opinión en contra RoBLedo VILLAR (2001) 376-7.

16 Con esos términos, Casero Linares (2001) 30-1.

17 Como indica Cordón Moreno (2001a) 414, "no se entiende cuáles pueden ser estos motivos razonables, en especial, cuando se reconocen al órgano judicial facultades para controlar el contenido del acuerdo que se alcance". 
atendida la vigencia del principio dispositivo (art. $5^{\circ}$ y concordantes ACPC) y la carencia de unas mínimas exigencias formales en la solicitud. Será necesario que en el caso concreto el juez analice las razones que puedan justificar su denegación y que consistirían en que eventualmente apreciara algún ánimo dilatorio que derivaría de eventuales suspensiones o retrasos de facto, o también intención de perjudicar la ejecución, a las partes o a terceros en la misma ${ }^{18}$.

En fin, cumpliéndose estos requisitos, dudosamente concretados por esta mejorable redacción del art. 459 ACPC, el juez adoptará la decisión de convocar la comparecencia mediante providencia. Queda en principio la incertidumbre de si cabrá algún tipo de impugnación frente a esta resolución, puesto que se presenta como dudosa la posibilidad de formular reposición dada la imprevisión específica y la referencia a "las sentencias interlocutorias y de los decretos dictados fuera de audiencias" que realiza el art. 341 ACPC. Aunque si atendemos al inciso cuarto del art. 194 ACPC, por el que "se llama decreto, providencia de mera sustanciación o proveído las que tienen por objeto dar curso progresivo al procedimiento, sin distinguir ni prejuzgar ninguna cuestión debatida entre partes", parece que frente a la providencia por la que se decida la celebración de la audiencia cabrá reposición. Este "recurso" no tendrá efecto suspensivo, sin perjuicio de lo previsto en el difícilmente entendible inciso segundo del art. $344 \mathrm{ACPC}^{19}$.

\subsection{Principales caracteres de la audiencia o comparecencia}

En primer lugar, la regulación de esta audiencia o comparecencia destaca por la amplia libertad subjetiva y objetiva que otorga. Hasta tal punto es así que en el inciso tercero del art. 459 ACPC se autoriza a que ejecutante y ejecutado puedan invitar a otras personas para que concurran junto a aquellos.

Desde un punto de vista subjetivo las posibilidades son amplísimas. Es más, ha de decirse que no resulta lógico que la posibilidad de invitación en la literalidad del precepto se limite únicamente a ejecutante y ejecutado cuando otros sujetos (los que acrediten "interés actual y directo en la ejecución"), conforme al inciso primero del mismo art. 459, tendrán igualmente la facultad de pedir la convocatoria Parece razonable que la fa-

18 En ese sentido, Franco Arias (2000) 3273. Por su parte, Hoya Coromina (2000) 2998, cita como ejemplo el posible perjuicio a tercero que pueda comportar. Para CASERo LiNARES (2001) 31, dado que, en principio, no hay suspensión de la ejecución, considera que no puede entenderse que serán motivos los simplemente dilatorios. Este autor y obra se refiere genéricamente a "posibles peticiones infundadas que tiendan a entorpecer de alguna forma la ejecución".

19 Según el mismo, "el tribunal podrá suspender o no los trámites del juicio o la ejecución de la sentencia impugnada por una reposición de una resolución pronunciada fuera de una audiencia, si la acogiere a tramitación y según la naturaleza de la impugnación efectuada". 
cultad de pedir la convocatoria de la comparecencia habría de llevar implícita también la de invitación, y así habría de desprenderse del tenor literal del precepto. Otra cosa es que los invitados puedan tener la facultad a su vez de invitar, como mantienen algunos autores en relación al equivalente art. $460 \mathrm{LEC}^{20}$.

El fin principal de esta invitación será generalmente que estas personas puedan adquirir el bien ofreciendo un precio "previsiblemente superior al que pudiera lograrse mediante la subasta judicial". Ya me he referido a la incongruencia que implica esta frase, traída directa y literalmente del art. 640.2.II LEC, en cuanto remite a una subasta judicial "desterrada" del texto del ACPC. Solamente tendría sentido lógico si en esta expresión se sustituyera la referencia a la "subasta judicial" por "otros medios de realización" o expresión similar, que, conforme al actual ACPC, remita a la realización por persona o entidad especializada tal y como se regula en el art. 460 ACPC.

Por lo demás, no cabría excluir que también fueran invitadas otras personas a distintos efectos, como sería participar de diferentes formas en la realización. Así por ejemplo, sería razonable poder invitar, por ejemplo, a peritos en la materia que trate el convenio, o a un administrador que pretenda nombrarse para la gestión en cobro de un bien productivo...21

Desde un punto de vista objetivo la libertad es también muy amplia. Parece que todos los comparecientes libremente podrán proponer cualquier forma de realización de los bienes sujetos a la ejecución y presentar a persona que, consignando o afianzando, se ofrezca a adquirir dichos bienes por un precio previsiblemente superior al que pudiera lograrse a través de otros medios de realización. Es más, no parece que deban limitarse a medios de realización, sino que nada excluye que pudiera haber igualmente libertad para proponer cualquier otro modo de "satisfacción" del derecho del ejecutante, aunque no consistiera estrictamente en un medio de realización. Parece conveniente, y así habría de derivar del precepto, que el objeto del convenio no excluyera formas de "compensación" a favor del ejecutante a partir de otros bienes o derechos distintos a los que fueran objeto de realización.

A pesar de esta línea de dotar amplitud, parece que el precepto introduce una limitación relevante al exigir que el precio que resulte de la propuesta formulada por los comparecientes sea "superior", si bien con el ma-

En la doctrina española, el art. 640.2 LEC igualmente menciona solo que invitarán ejecutante y ejecutado, sin embargo, como opina, con base en el art. 14 CE (igualdad ante la ley), Franco Arias (2000) 3274, la facultad para comparecer incluirá también la de invitar a otros. Con alguna mayor prevención, Pedraz Penalva/Moral Moro (2001) I-63, opinan que podrán asistir invitados de los interesados. con la amplitud del contenido del convenio que se pueda alcanzar.
} 
tiz de que lo sea "previsiblemente". En realidad no supone una limitación verdaderamente eficaz por varias razones: por lo imprecisa que resulta ${ }^{22}$, porque el resultado final de una subasta judicial o de cualquier otro modo de realización siempre es incierto, y porque el hecho de que un precio pueda ser "previsiblemente" superior no supone que al final lo sea realmente. Como mucho, la exigencia supondrá en la práctica que se deba efectuar una previsión orientativa de lo que en realidad es habitual y por eso previsible obtener, derivada de la experiencia o, de haberla, de la estadística.

En segundo lugar, la audiencia o comparecencia se caracteriza por no tener efectos suspensivos hasta que esta culmine con acuerdo (inciso cuarto art. 459 ACPC).

Esta previsión de no suspensión posiblemente tenga la finalidad que la solicitud de comparecencia por parte de ejecutado o terceros pueda instrumentarse para dilatar el proceso de ejecución. Sin embargo, en general, no tiene mucho sentido pues requiere aceptación del ejecutante, y ningún sentido cuando la solicita el propio ejecutante.

No queda claro si la no suspensión implica que el procedimiento de apremio (lo previsto en el art. 460 ACPC) seguiría su marcha tanto en lo ya acordado como en lo que pudiera acordarse en el futuro, o bien si solamente se seguiría con lo acordado sin señalar nuevos actos hasta el resultado de la comparecencia ${ }^{23}$. Y en todo caso, no cabe descartarse la posibilidad de que pueda ser conveniente que se suspenda la realización por otras vías.

Pero es que, además, hay motivos razonables para entender tal previsión como poco acorde con el propio proceso civil y con los principios que lo inspiran. Siendo que la comparecencia ha de ser al menos aceptada por el ejecutante, y atendido el art. 413 ACPC (al igual que su correlativo 565 LEC) por el que cabrá la suspensión cuando "así lo acuerden todas las partes personadas en la ejecución", parece que tendrá que proceder la suspensión cuando se solicite el convenio en la mayoría de las ocasiones pues así lo vendrán a acordar de un modo o de otro ejecutante y ejecutado. Suspensión esta que puede ser además muy conveniente y hasta necesaria para la viabilidad del "mejor" modo de realización, cuando el avanzado estado de la realización por persona o entidad pudiera hacer inviable el posible

22 Pedraz Penalva / Moral. Moro (2001) I-36, advierten que esta condición relativa no es de fácil cumplimiento, requiriéndose a tal efecto, según expresan, "facultades premonitorias para conocer lo que no ha existido". En esa línea, CASERo LiNAREs (2001) 33, señala que la norma resulta altamente imprecisa pues establece la comparación en un juicio de previsibilidad que en la realidad puede tener resultados muy variados, la referencia puede ser tanto el precio tasado o el mínimo que se prevé en cada caso.

23 BANACLOCHE (2001) 1113, parece inclinarse por esta última posibilidad cuando afirma que "está haciendo referencia a que no se paralizan los trámites que, para la subasta judicial del bien o derecho de que se trate, se hayan podido acordar". 
acuerdo $^{24}$. Desde luego, no parece que la solución correcta a esta necesidad venga de una práctica correctora consistente en suspender de facto los actos de la ejecución.

En definitiva, no tiene sentido establecer la no suspensión de la ejecución cuando la propia solicitud de comparecencia y en todo caso su aceptación (expresa) por el ejecutante, constando la falta de oposición del ejecutante e interesados, si concurren los requisitos viene a suponer en la práctica una solicitud de suspensión en los términos del art. 413 ACPC, acorde por lo demás con el respeto a la autonomía de la voluntad y con el poder de disposición de las partes (art. 5 ACPC).

En tercer lugar, la comparecencia podrá ser reiterada en el caso de que no se logre el acuerdo (incluido si no comparece ejecutante o ejecutado). Esta posibilidad no ofrece dificultad alguna dado que, en principio y salvo lo señalado antes, si no se ha suspendido trámite alguno de la ejecución, el "tribunal" no tendrá que ordenar nada en relación con la anterior comparecencia frustrada. Parece correcto que sea posible repetir la comparecencia con los mismos requisitos y además cuando las circunstancias del caso lo aconsejen, a juicio del tribunal, para la mejor realización de los bienes (art. 459 último inciso ACPC), si bien habrá que prestar atención de que no se utilice por el ejecutado o terceros para intentar dilatar indebidamente el procedimiento ${ }^{25}$.

Por último, se prevén requisitos adicionales en el supuesto de que el objeto del convenio sea la adquisición por un tercero. En tal caso, se exige que el precio ofrecido sea "previsiblemente superior" y que el tercero afiance o consigne el precio. Sobre lo primero ya he indicado su relativa importancia. En cuanto a lo segundo, destaca por la absoluta imprevisión de los mínimos elementos para su aplicación práctica. Para ello convendría que se concretara el plazo en que deba producirse tal consignación o afianzamiento, sea simultáneamente al convenio o bien concediendo un plazo suficiente $^{26}$; y también que se expresara el porcentaje sobre el valor de tasación del bien que permitiría calcular exactamente el importe de dicho afianzamiento o consignación.

Esta posibilidad, dado el tenor literal del art. 640.2 LEC, no es reconocida mayoritariamente por la doctrina española. Así, por ejemplo, CORDón Moreno (2001a) 413, para evitar este problema afirma que "la solicitud deberá realizarse dentro de un tiempo razonable anterior a la fecha de la celebración de la subasta, si ésta ya hubiera sido convocada".

En relación con su correlativo art. 640.5 LEC, advierte Redondo García, Fernando (2000) "Líneas generales del procedimiento de apremio". En Alonso-Cuevillas (Coord.) Instituciones del Nuevo Proceso civil. Comentarios sistemáticos a la Ley 1/2000, III. Barcelona, Economist\&Jurist, p. 354, que esta posibilidad puede ser utilizada por el ejecutado y/o el interesado de mala fe para dilatar el procedimiento.

En esa línea algún autor como Hoya Coromina (2000) 3000. 


\section{El convenio de realización}

Este convenio, de naturaleza en principio privada pero sometida a aprobación judicial, adquiere naturaleza compleja, sui generis, integrado por factores contractuales y procesales ${ }^{27}$.

\subsection{Las excesivas dificultades para su aprobación}

La aprobación del acuerdo, en principio libre para las partes, está sometido a ciertos límites objeto de control judicial. En mi opinión, aquí radica la clave porque precisamente estos límites son los que han provocado la poca viabilidad práctica de este medio de realización en el derecho español.

En el supuesto de que se llegare a un acuerdo exclusivamente entre ejecutante y ejecutado, se exige que "no pueda causar perjuicio para tercero". Por supuesto, no se atenderá a este límite si el acuerdo "incluyere la conformidad de los sujetos, distintos de ejecutante y ejecutado, a quienes afectare". Así, por tanto, solamente no causando perjuicio para tercero, o, si lo pudiere causar, contando con su conformidad, el juez aprobará el convenio mediante "resolución" y además "suspenderá la ejecución respecto del bien o bienes objeto del acuerdo". Asimismo, con carácter especial, cuando el convenio se refiera a bienes susceptibles de inscripción registral (cosa muy habitual, especialmente cuando se trata de importes elevados) se concreta la anterior previsión general imponiendo que "será necesaria, para su aprobación, la conformidad de los acreedores y terceros poseedores que bubieran inscrito o anotado sus derechos en el Registro correspondiente con posterioridad al gravamen que se ejecu$t a "$. Incluso, de conformidad con los derechos de igualdad y tutela judicial efectiva, también habría de ser precisa la conformidad de los titulares de cualquier otro derecho que fuera conocido en autos ${ }^{28}$.

Si bien se mira, esta misma exigencia ha provocado en la práctica española la inutilidad de este medio de realización, puesto que, como en la mayoría de ocasiones se producirá perjuicio para terceros, implícito potencialmente en todo medio de realización, todo el mecanismo de realización se hace depender al final de la voluntad de estos terceros.

No se matiza, de otro lado, si esta conformidad podrá o no ser tácita. Parece razonable entender que bastará con la no oposición al convenio ${ }^{29}$.

27 CORdón MORENO (2001a) 415.

28 Franco Arias (2000) 3276. De otro lado, algún autor como Vegas Torres (2000) 263, matiza razonablemente que esta exigencia no se aplicaría, aunque se trate de este tipo de bienes, si por su contenido no es susceptible de causar perjuicios a los titulares de derechos inscritos o anotados con posterioridad (por ejemplo, si el precio permite pagar a todos).

29 En ese sentido, entre otros, Cordón Moreno (2001a) 415. Sin embargo, mantiene la opinión contraria Hoya Coromina (2000) 3000. Pedraz Penalva / Moral Moro (2001) 
En tal caso, de nuevo, se hace necesario completar la regulación con la previsión de las actuaciones necesarias para su viabilidad, por ejemplo, previendo las pertinentes notificaciones otorgando un plazo para tal manifestación ${ }^{30}$.

El resto de exigencias son menores. Como he indicado antes, el requisito del precio previsiblemente superior tiene una viabilidad relativa; y solamente es aplicable al caso concreto de persona que, consignando o afianzando, adquiera los bienes, y no para cualquier otro medio de satisfacción. Es más, no cabe excluir otras hipotéticas ventajas para las partes que puedan hacer prescindible ese precio previsiblemente superior (como posible rapidez en la realización, estrategias empresariales o comerciales de futuro entre las partes, etc.), cuestiones que han de atenderse como se desprende del hecho de que, con respeto de la autonomía privada, no se exija al final para la aprobación judicial del convenio, sino solamente para aprobar la comparecencia ${ }^{31}$.

El inciso cuarto del art. 459 ACPC dispone que se aprobará mediante "resolución" 32, y, aunque ninguna referencia haya al respecto, de igual forma habría de resolverse en caso de no aprobación del convenio. Quizá resultara más claro el precepto si se indicara no que "se aprobará" sino que se "decidirá" mediante resolución, de modo que incluyera ambas posibilidades.

Tampoco se expresa nada sobre las posibilidades de recurso frente a esta resolución. Convendría que se matizara de algún modo, y se aclarara si será posible recurso realmente eficaz (devolutivo) especialmente frente al auto de no aprobación.

\subsection{Efecto suspensivo de la aprobación}

La aprobación del acuerdo ahora sí en todo caso produce la suspensión de la ejecución en lo que se refiere a los medios de realización ordinarios que resulten incompatibles. Por supuesto, se producirán siempre respecto de los trámites de la ejecución consistentes o preordenados a trasladar

I-64, consideran que cuando los terceros no estuviesen presentes en la comparecencia y fueren conocidos, deberán ratificarlo mediante comparecencia en el juzgado.

Franco Arias (2000) 3275, opina que, en caso de desconocerse el domicilio, será suficiente con la notificación no personal (la edictal prevista en el art. 164 LEC).

Argumenta Vegas Torres (2000) 262, que "no tiene mucho sentido y, quizá los tribunales no deberían prestarle especial atención, la indicación de que el precio que ofrezca el comprador sea 'previsiblemente superior...'. Lo relevante debe ser que el precio sea suficiente para dar satisfacción al acreedor y, en su caso, a los acreedores posteriores y que la venta a ese precio cuente con la conformidad del dueño de los bienes, sea el ejecutado o un tercer poseedor".

En relación con el correlativo art. 640 LEC, indica CASERo LiNARES (2001) 34, que en el auto debería hacerse saber claramente a las partes y a los adquirentes que las enajenaciones no pueden tenerse por válidamente realizadas hasta que sean aprobadas por el "tribunal" de la ejecución. Robledo VilLaR (2001) 378, señala que el auto contendrá una descripción suficiente del acuerdo, así como su plazo de ejecución (opino que solamente de haber sido este pactado). 
el bien o derecho objeto de convenio, en caso de que el convenio afecte solamente a este (por ejemplo, adquisición por precio previsiblemente superior por un "invitado") y que por sí mismo no suponga la satisfacción total. Respecto de otros posibles medios de realización igualmente se suspenderían en cuanto resultaren incompatibles.

\subsection{Cumplimiento o incumplimiento del acuerdo}

El cumplimiento del acuerdo parece que debería requerir acreditación ${ }^{33}$. Y tendrá como efecto, en caso de que se haya obtenido la satisfacción completa del ejecutante, el fin de la ejecución (art. 415 ACPC); y si esta es parcial, se producirá en todo caso el sobreseimiento de la ejecución respecto del bien o bienes a que se refiriese (inciso sexto del art. 459 ACPC).

Siendo el objeto del convenio la enajenación de bien inmueble, será de aplicación el régimen general de cancelación de embargos y medidas cautelares a que se refieren los arts. 461 y 463 ACPC.

El incumplimiento dentro del plazo pactado o si, por cualquier causa, no se lograse la satisfacción del ejecutante en los términos convenidos, permitirá a este pedir que se alce la suspensión de la ejecución y se proceda a la realización mediante "subasta, en la forma prevista en esta ley". Como ya he indicado, esta referencia no parece muy precisa, puesto que más bien procederá la realización por persona o entidad especializada en los términos previstos en el art. 460 ACPC.

Nada se expresa sobre si sería posible instar el cumplimiento forzoso del convenio o, al menos, exigir responsabilidades derivadas del mismo. Convendría que se hiciera una mención que, a diferencia de lo que ocurre en la LEC, diera una respuesta a esta cuestión ${ }^{34}$.

\section{REFLEXIONES SOBRE LA REALIZACIÓN A TRAVÉS DE PERSONA O INSTI- TUCIÓN ESPECIALIZADA CONFORME SE PROPONE EN EL ART. 460 ACPC}

Como he indicado, la gran novedad del sistema previsto en el ACPC es que, con correlación con el art. 456 ACPC y a diferencia de lo previsto

33 Así lo sostiene, entre otros, Robledo Villar (2001) 379.

34 Doctrina autorizada española como FrANCO ARIAS (2000) 3276-7, se muestra a favor de esta posibilidad por aplicación analógica del art, 476 LEC 1881 (vigente por la disposición derogatoria segunda) relativa a lo convenido en conciliación, y del art. 415 LEC respecto a los convenios alcanzados en la audiencia previa del juicio. Similarmente, Pedraz Penalva / Moral Moro (2001) I-64, consideran que podrá acudirse ante el mismo órgano jurisdiccional para exigir el cumplimiento de lo convenido, atendiendo a lo establecido en el art. 415.2 LEC en relación con el acuerdo homologado judicialmente, que surtirá los efectos atribuidos por la ley a la transacción judicial y podrá llevarse a efecto por los trámites previstos para la ejecución de sentencias y convenios judicialmente aprobados. 
en el art. 641 LEC, "a falta de acuerdo entre ejecutante y ejecutado, el tribunal acordará mediante resolución, que el bien lo realice una persona o institución especializada y conocedora del mercado en que se compran y venden esos bienes y en quien concurran los requisitos legalmente exigidos para operar en el mercado de que se trate". La novedad de este precepto y su carácter general, por proceder al faltar convenio ${ }^{35}$, provocan que este modo de realización adquiera una trascendencia extraordinaria. Se impone de ese modo que su regulación se caracterice, si cabe, por una mayor calidad técnica.

La realización de bienes se extrae del ámbito del Poder Judicial. Sin duda, se trata de una decisión que forma parte de la libertad de configuración que corresponde al legislador y que, por tanto, al margen de otras consideraciones habrá de ser valorada principalmente por sus resultados. Sin perjuicio de lo que indicaré en el último punto de este trabajo, solamente adelantaré ahora que en cualquier caso no se produce una verdadera "desjudicialización" puesto que más bien implica una delegación de actuaciones concretas cuya adecuación legal ha de ser constantemente verificada por el órgano jurisdiccional ${ }^{36}$.

Lo bien cierto es que, aunque con una redacción mejorable ${ }^{37}$, el art. 460 ACPC impone que la falta de acuerdo en el convenio entre ejecutante o ejecutado (o cuando no se aprobare este por perjudicar a terceros y no constar la conformidad de los acreedores y terceros poseedores que hubieran inscrito o anotado sus derechos en el Registro correspondiente con posterioridad al gravamen que se ejecuta) suponga irremediablemente que la realización se lleve a efecto por persona o entidad especializada y conocedora del mercado en que se compran y venden esos bienes y en quien concurran los requisitos legalmente exigidos para operar en el mercado de que se trate. En este último caso, "la enajenación se acomodará a las reglas y usos de la casa o entidad que subaste o enajene, siempre que no sean incompatibles con el fin de la ejecución y con la adecuada protección de los intereses de ejecutante y ejecutado".

Nada nos indica en cambio cómo habrá de procederse en el supuesto, poco probable pero posible, de que la entidad especializada no contara con tales reglas. Convendría alguna previsión al respecto, como la indicación

En el ordenamiento español se introduce con la LEC 1/2000, si bien ya contaba con un precedente en el ámbito del proceso laboral. Dispone el art. 261.1 Ley de Procedimiento Laboral que "para la liquidación de los bienes embargados, podrán emplearse estos procedimientos: a) Por venta en entidad autorizada administrativamente con tal fin, si así lo acordara el órgano judicial, cualquiera que fuere el valor de los bienes". Para Pedraz Penalya / Moral Moro (2001) I-85, la misma sería contraria a los arts. 117.3 y 24.2 CE y 2.1 LOPJ.

37 Como he indicado antes, no resulta consecuente que el inciso segundo se inicie con "también..." cuando en el anterior ya se hablaba de la posibilidad de realización por "institución". Por otra parte, las posibilidades de esta realización no se limitan a la falta de acuerdo como parece desprenderse del inciso segundo del mismo art. 460 ACPC. 
de que la realización se instrumentará mediante las reglas propias del mercado, atendiendo los intereses de la ejecución y con salvaguarda de los intereses del ejecutante y del ejecutado ${ }^{38}$.

Por lo que se refiere al objeto de este modo de realización, según el tenor literal del mismo art. 460 ACPC, parece derivar que será única y exclusivamente la enajenación de un determinado bien o bienes del ejecutado. Junto a las reiteradas alusiones genéricas a la "realización", se habla de persona o institución "conocedora del mercado en que se compran y venden esos bienes" (inciso primero), "que el bien se enajene" y "la enajenación" (inciso segundo), o "enajenados" (inciso quinto). Desde luego que esta enajenación será el modo de realización que se practicará habitual y normalmente, sin embargo, a mi juicio no por ello tendría que ser excluidas o cerradas per se otras posibilidades que derivaran en satisfacción a favor del ejecutante, como podría ser la adopción de una hipotética atribución del bien o derecho a una persona o entidad especializada para que con el producto de la gestión del mismo bien o derecho hacer pago al ejecutante con el saldo resultante.

Por último, solamente indicar que a diferencia de lo previsto en el art. 459 ACPC, como en este supuesto ahora se halla en principio definido su objeto, los esfuerzos de la norma no se dirigen a que se adopte un acuerdo con garantías entre las partes, sino, dada la delegación judicial, a que la realización, y en especial la posible enajenación, se lleven a efecto previo cumplimiento de unas exigencias, dentro de unos límites y con cautelas generales y particulares.

\section{Exigencias generales para que una persona o entidad determi- nada asuman este sistema de realización}

A diferencia de lo que prevé la LEC y como consecuencia de que se aplicará en general solo por la falta de un convenio aprobado, las exigencias, límites y cautelas para que pueda adoptarse este medio de realización se limitan a que la persona o entidad cumpla unos requisitos determinados, sin necesidad de solicitud ni que las características del bien aconsejen esta modalidad.

Dado este carácter general con que se le dota en el ACPC, podrá acordarse en cualquier momento en que conste la falta de acuerdo así como la de aprobación del convenio. Por supuesto será así siempre que nos encontremos en un proceso de ejecución pendiente, y más concretamente cuando al menos un bien resulte "embargado", sin perjuicio de que pueda igual- 
mente ser conveniente (aunque no necesariamente) que se haya realizado previamente el avalúo ${ }^{39}$.

\subsection{Requisitos en la persona o en la entidad: conocimiento del mer- cado en que se compran y venden los bienes $y$ "requisitos legal- mente exigidos"}

La redacción en este punto, exactamente igual a lo que ocurre con la LEC, no puede calificarse como un alarde de claridad ni corrección. Ambos preceptos aluden a "persona o institución especializada y conocedora del mercado en que se compran y venden esos bienes y en quien concurran los requisitos...". De ese modo, con la única salvedad de que el verbo concurrir se conjuga en tercera persona del plural, parece limitar, a todas luces erróneamente, el conocimiento del mercado en que se compran o venden los bienes y los requisitos legalmente exigidos solamente a la entidad especializada. Sin embargo, a pesar de que pueda ser menos habitual que carezca de estos requisitos una persona jurídica, sobre todo si es pública, parece claro que estos requisitos son exigibles a toda persona física o jurídica sea pública o privada, y con esa claridad y rotundidad debería redactarse el inciso primero del art, 460 ACPC.

Cierta deficiencia se aprecia en el texto de este art. 460 ACPC por la ausencia de una mínima referencia a la acreditación de tales requisitos. Queda la duda de si corresponderá al solicitante o a la entidad ${ }^{40}$. Así y todo, ha de reconocerse que este problema se minimiza en el derecho chileno, aunque sea parcialmente, en la medida de que la entidad (sin referirse a la persona física en el inciso tercero del art. 460 ACPC) en cuanto se halle registrada en la "Corporación del Poder Judicial" habrá tenido que cumplir para ello con "los requisitos que se contemplen en el Reglamento que debe regular esta materia"; y se supone que entre estos requisitos se encontrará al menos contar con el conocimiento correspondiente y los requisitos legalmente exigidos. Asimismo, en el resto de supuestos cabe entender por su parte que el requisito del conocimiento en el mercado pueda darse por supuesto cuando se trate de entidades públicas ${ }^{41}$, o pueda colegirse

Vegas Torres (2000) 264, argumenta que la actividad de avalúo y las del art. 666 LEC son necesarias para fijar las condiciones de venta, de modo que la petición solamente podrá realizarse después. En mi opinión, por el contrario, puede que sea conveniente y útil, pero no jurídicamente imprescindible, conocer el valor dado a los bienes para que pueda solicitarse y adoptarse este sistema de realización, sin perjuicio de que sí pueda serlo para realizar los actos propios tendentes a la realización por persona o entidad especializada. Según Hoya COROMINA (2000) 3004, los requisitos legales deberán documentarse en el procedimiento por la entidad.

41 Cordón MOREno, Faustino (2001b) "Realización por persona o entidad especializada". En Cordón, Armenta, Muerza y Tapia (coor.). Comentarios a la Ley de Enjuiciamiento Civil, II. Elcano: Aranzadi, p. 420, pone de manifiesto esta carencia, y opina que solamente en caso de entidades públicas podrá darse por supuesto el cumplimiento de los requisitos. 
igualmente la concurrencia de este conocimiento por la legalidad de la actuación de personas jurídicas en el mercado concreto. Incluso podría presumirse este conocimiento con la sola acreditación del tiempo en que la persona haya actuado en el mercado.

Por último, se echa en falta alguna indicación sobre cómo habría de procederse si la persona o entidad no cumpliesen los requisitos, por mucho que pueda parecer obvio que cabrá la posibilidad de designar a otra persona debidamente habilitada ${ }^{42}$.

\subsection{Prestación de caución por personas o determinadas entidades es- pecializadas}

En este punto concreto hay una diferencia significativa con el derecho español. En la LEC habrá de prestar caución cualquier persona o entidad especializada privada, esto es, todas salvo las entidades públicas. En cambio en la previsión del art. 460 ACPC, las personas o entidades, privadas o públicas, prestarán la caución, salvo "cuando la realización se encomiende a una entidad registrada en la Corporación del Poder Judicial, la que deberá cumplir para ello con los requisitos que se contemplen en el Reglamento que debe regular esta materia".

De esta previsión deriva una discriminación inicial respecto de las personas físicas en cuanto no se prevé la posibilidad de que puedan acceder a un registro limitado exclusivamente a entidades. Trato desigual difícilmente justificado a estos efectos y que, de llevarse a la práctica, supondrá como efecto dudosamente conveniente el fomento de las constituciones sociales en este ámbito de ejercicio profesional o empresarial.

De otro lado, aunque con toda probabilidad en la práctica toda persona pública se encontrará registrada, lo bien cierto es que con independencia de la incorporación "formal" de una entidad pública en dicho registro, se justificaría en todo caso la exención de la caución ${ }^{43}$.

Igualmente, como ocurre con la LEC, el art. 460 ACPC omite alguna referencia que convendría no dejarse a la labor creativa del juez o del operador jurídico. Entre las más importantes, habría de concretar el importe de la caución, o al menos el modo de determinarla. Al no decirse nada, parece que habrá de quedar a la discrecionalidad judicial, siendo el momento idóneo para su determinación la resolución que acuerde este modo de realización ${ }^{44}$. Ante la falta de concreción legal, la doctrina española ha ido

\footnotetext{
42 Así lo entiende, Redondo García (2000) 355.

43 Pedraz Penalva / Moral Moro (2001) pp. I-84, entiende justificada esta exención por la solvencia de que gozan estas entidades, de modo parejo a las exenciones de depósitos y cauciones (art. 12 Ley 52/1997).

44 En ese sentido, en relación con el correlativo art. 461 de la LEC, Cordón Moreno (2001b) 421 .
} 
aportando algunos posibles criterios más o menos lógicos. Así, habría de depender en primer lugar del valor del bien a realizar y también de la solvencia de la persona o entidad ${ }^{45}$; asimismo, debería fijarse prudentemente de modo que no fuera tan alta que hiciera poco asumible el encargo, ni tan baja que perdiera su finalidad. En fin, algún autor aporta además algún criterio objetivo como pauta: la fijación de un importe equivalente al depósito previo para licitar, sin perjuicio de que se acabara de ajustar en cada caso concreto ${ }^{46}$.

Por último, nada se regula sobre la posibilidad de aceptación ni el plazo en que este se deba producir y, como consecuencia, el momento en que ha de ser prestada la caución. Como ocurre con la fijación del importe, parece que igualmente queda a la fijación discrecional del "tribunal" ${ }^{47}$. A tal efecto, aunque tampoco se regula, habría de integrarse la instrumentación de una notificación o requerimiento a la persona o entidad especializada para que proceda a la aceptación y al ingreso de la caución en el plazo fijado, con la advertencia de perder el encargo en caso de incumplimiento. $\mathrm{Y}$ ante tal eventualidad, no estaría de más que se estableciera una segunda o tercera alternativa ${ }^{48}$.

\subsection{Determinación de las condiciones en que deba efectuarse la realización}

La misma resolución que la acuerde determinará las condiciones en que deba efectuarse la realización. Para ello habrá de partir de que con carácter general las condiciones serán las pactadas por las partes y, a falta de acuerdo, específicamente se prohíbe que los bienes sean "enajenados por precio inferior del avalúo"; y se determinarán, por ejemplo, fijándose la remuneración de la persona o entidad, la forma y condiciones de pago del precio, un precio mínimo o un plazo máximo, etc. Todo esto teniendo en cuenta que según el inciso sexto del mismo art. 460 ACPC, en relación con los bienes inmuebles, el juez "no podrá autorizar que la enajenación se realice por precio inferior al valor de tasación que se haya dado al inmueble con arreglo a lo previsto en el artículo 458 , salvo que conste el acuerdo de las partes y de todos los interesados, hayan asistido o no a la comparecencia"; y que conforme al inciso octavo del mismo art. $460 \mathrm{ACPC}$, en principio el plazo no podrá superar los seis meses, prorrogables por otros seis cuando se den las condi-

Así, Casero Linares (2001) 1117, se refiere a que atenderá al valor del bien y a lo indicado por las partes.

FRANCO ARIAS (2000) 3281.

Hoya COROMina (2000) 3005, considera que en el trámite de acreditación de que la persona o entidad reúnen los requisitos del art. 641.1 LEC, deberá requerirse la aceptación como previo a la aportación de la caución.

18

FrANCO ARIAS (2000) 3281. 
ciones que el mismo precepto establece (se justifique por la persona o entidad que la realización no ha sido posible en el plazo indicado por motivos que no le sean imputables y que, por haber desaparecido ya dichos motivos o por ser previsible su pronta desaparición, el encargo podrá cumplimentarse dentro del plazo que se ofrezca) $)^{49}$.

Las partes, por tanto, tienen en principio libertad para establecer las condiciones en que se desarrollará la realización. Ni siquiera las posibles reglas y usos de la casa o entidad a la que correspondiera subastar o enajenar prevalecerían sobre las acordadas por las partes ${ }^{50}$. Estas serían reglas especiales que prevalecerán sobre las de la entidad, que se aplicarían como generales. Solamente en caso de falta de acuerdo se limita a que ta enajenación del bien mueble o inmueble no sea por valor inferior al del ava$\operatorname{lú}^{51}$. Todo ello sin perjuicio de que quepa entender que todas las reglas, especiales acordadas y generales, no habrán de ser incompatibles con el fin de la ejecución y con la adecuada protección de los intereses de la parte ejecutante y ejecutada.

Al contrario de lo que hemos visto que ocurre en el art. 459 ACPC, la salvaguarda de los intereses de los terceros interesados no se recoge en la literalidad del art. 460 ACPC como condicionante de la aprobación de las condiciones en que deba efectuarse la realización. Convendría que en el texto de este art. 460, aunque no lo contenga el correlativo art. 641 LEC, se hiciera alguna previsión sobre la protección de estos terceros, pues no parece que en la libertad de configuración quepa amparar condiciones que de algún modo impliquen menoscabo ilegítimo de los derechos e intereses de los terceros interesados ${ }^{52}$.

Por otra parte, el art. 461 ACPC impone que se aprueben judicialmente las enajenaciones "previa comprobación de que la venta del bien se produjo con conocimiento de los tribunales que bubieran decretado los embargos y medidas cautelares que afecten al bien enajenado", lo que permite afirmar que entre las condiciones de la enajenación deberá consignarse la necesidad de que la persona o entidad enajenante haga constar y ponga en conocimiento la enajenación a estos órganos ${ }^{53}$.

Algún autor, como Moreno Catena (2000) 218, matiza que este plazo de seis meses podría ampliarse de conformidad con lo acordado por las partes y se decidiera en la providencia.

Algún autor, como Rodríguez Ruiz de ViLLA, Daniel (1998) "Reflexiones sobre el avalúo y la subasta de inmuebles en el Anteproyecto de Ley de Enjuiciamiento Civil". La Ley, 4, pp. 1491-97, postula a estos efectos la remisión de la LEC a la Ley 7/1996, de 15 de enero, sobre Ordenación del Comercio Minorista. (arts. 56 a 61).

51 Algún autor como VeGas Torres (2000) 265, opina que en defecto de pacto, el juez acordará las que considere más convenientes.

52 En ese sentido Franco Arias (2000) 3280.

53 En derecho español, el art. 642.2 LEC hace una previsión que se parece a la anterior pero que difiere sustancialmente. Este precepto impone que se aprueben judicialmente las enajenaciones "previa comprobación de que la transmisión del bien se produjo con conocimiento del adquirente, de la situación registral que resulte de la certificación de cargas", de modo que 
Igualmente, entre las mismas condiciones habrán de encontrarse el cumplimiento de los plazos previstos en el inciso octavo del art. 460 $\mathrm{ACPC}^{54}$.

\section{Exigencias, límites y cautelas particulares para la adopción de este sistema de realización}

Los límites y exigencias generales anteriores se refuerzan cuando los bienes a realizar son inmuebles con nuevas exigencias:

\subsection{Comparecencia}

A los efectos de la determinación de la persona o entidad a la que vaya a confiarse la realización y de las condiciones en que esta deba efectuarse, se impone una previa comparecencia a la que serán convocadas las partes y quienes conste en el proceso que pudieran estar interesados ${ }^{55}$, resolviendo el tribunal lo procedente mediante "providencia" a la vista de las manifestaciones de quienes asistan. Por lo tanto no se prevé como ninguna suerte de obligación sino meramente como carga ${ }^{56}$.

El objeto de esta comparecencia determina expresamente en la determinación de la persona o entidad y de las condiciones de la realización, lo que no debería excluir que en la misma comparecencia pudiera tratarse la posibilidad de establecer un convenio en los términos del art. 459 ACPC.

\subsection{Necesario acuerdo cualificado en ciertos casos para que se autori- ce la enajenación}

Será necesario que conste el acuerdo de las partes y de todos los interesados, hayan asistido o no a la comparecencia, para que la enajenación se realice por precio inferior al valor de tasación que se haya dado al inmueble con arreglo a lo previsto en el artículo $458 \mathrm{ACPC}$, que establece el

en derecho español entre las condiciones de la enajenación deberá consignarse la obligación de la persona o entidad enajenante de hacer conocer al adquirente la situación registral del bien embargado.

En ese sentido, en relación con el correlativo art. 641.5 LEC, CASERo LiNARES (2001) 46 y 48.

FranCO ARIAS (2000) 3281, defiende que siempre que el bien sea mínimamente relevante cabrá actuar como previene el art. 641.3 párrafo segundo LEC, celebrando la comparecencia prevista. Para Pedraz Penalva / Moral Moro (2001) I-84, también es indispensable la comparecencia en el supuesto de bienes muebles cuando deba oírse a los que acrediten un interés directo. Asimismo, ambos opinan que, atendido el art. 13 LEC, puede afirmarse la posible intervención de interesados aunque no consten en el proceso en cuanto acrediten la condición de tales. de venta acordadas en todo caso, se trata de un límite que impide al órgano jurisdiccional imponer otras diferentes, pero no controlar las que, por ejemplo, puedan perjudicar a terceros. 
modo de fijación, sea por acuerdo, la que conste en el "Rol de Avalúos" o pericialmente.

\section{Cumplimiento o incumplimiento del encargo de realización}

Observadas las cautelas y respetados los límites establecidos, al final puede o no haberse logrado el cumplimiento del encargo para la realización:

\subsection{Consumación de la realización}

Tan pronto como se consume la realización de los bienes se procederá por la persona o entidad correspondiente a ingresar en la cuenta corriente del tribunal la cantidad obtenida. De ese importe se descontará los gastos efectuados y lo que corresponda aquellas por su intervención (inciso séptimo del art. 460 ACPC).

Obvia es la importancia de los posibles gastos y remuneraciones de las personas o entidades especializadas. Sin perjuicio de que la remuneración pueda y suela consistir en un porcentaje de la cantidad obtenida que incluya todos los gastos, en caso contrario, sería muy conveniente contar con un presupuesto detallado, completo, aceptado y aprobado con el fin de no resultar sorprendidos y para evitar posibles fraudes y abusos. Y, lo que es más relevante a estos efectos, el "tribunal" habría de controlar tales gastos y honorarios en cuanto a través de los mismos podría perjudicarse el interés de la ejecución y de las partes ${ }^{57}$. A falta de dicho control, parece que tanto ejecutante como ejecutado, y hasta incluso todos los interesados ${ }^{58}$, habrían de tener derecho a impugnar los honorarios y gastos por indebidos y excesivos, de modo que el precepto debería contener alguna previsión al respecto. Derecho de impugnación que incluso habría de proceder, aunque fuera limitadamente, a pesar de que constare presupuesto detallado, para poder impugnar la inclusión de partidas por gastos indebidos o no realizados, así como el cobro de cantidades superiores a las presupuestadas. En el caso de gastos no presupuestados, habría que quedar justificada su necesidad y el carácter extraordinario para no haber sido incluido en la relación.

Lo bien cierto es que la operación requerirá aprobación judicial. A tal efecto, en su caso, se solicitarán las justificaciones oportunas sobre la realización y sus circunstancias. Esta operación supondría comprobar la calidad del encargo, lo que incluiría el que no se observe indicios de fraude o que se han practicado las suficientes actividades de publicidad. No obstante limitarse el ACPC a prever meramente esta aprobación, el control judicial

57 Véanse las consideraciones que realiza al respecto CASERo LINARES (2001) 47-8.

58 Franco Arias (2000) 3282. 
no habría de limitarse únicamente a la misma, sino que tendría que implicar el control de todo el periodo de realización ${ }^{59}$. Incluso tendrá facultad también para revocar el encargo en el caso que no se realice con las condiciones pactadas, con las reglas o usos de la entidad, o se observen actitudes en perjuicio de los intereses de la ejecución o de las partes, así como de los terceros interesados.

De no aprobarse la operación, cabe entender que no se producirá la entrega del bien al adquirente hasta que sea aprobada la operación mediante una "resolución" que no se determina en el precepto pero que parece que tendrá carácter constitutivo ${ }^{60}$. De no aprobarse, procedería la restitutio in integrum, consistente en la devolución del dinero entregado al adquirente, sin que nada se exprese tampoco sobre cómo habrá de procederse respecto de la caución eventualmente prestada.

Si se aprueba la operación, a diferencia de lo que ocurre con la LEC tampoco se prevé el destino de la caución eventualmente prestada, si bien parece que la consecuencia lógica es que habría de ser devuelta.

\subsection{Incumplimiento}

Habiéndose frustrada la realización, esto es, no llevada a cabo transcurridos seis meses desde el encargo (o incluso el plazo más breve que libremente se hubiera pactado), el tribunal dictará auto revocándolo. No obstante, se concederá nuevo plazo para su cumplimiento cuando se justifique por la persona o entidad que la realización no ha sido posible por motivos que no le sean imputables. Igualmente por haber desaparecido ya dichos motivos o por ser previsible su pronta desaparición, el encargo podrá cumplimentarse dentro de un plazo máximo de seis meses. Incumplido de nuevo, se revocará definitivamente (incisos octavo y noveno del art. 460 ACPC).

Se ha eliminado la previsión del art. 641 LEC sobre el destino de la caución. En este precepto se prevé que una vez revocado, la caución se aplicará a los fines de la ejecución, salvo que la persona o entidad que la hubiese prestado acredite que la realización del bien no ha sido posible por causas que no le sean imputables. Parece conveniente que se incorpore una previsión al respecto, de modo que, de un modo o de otro, se indemnice al ejecutante.

Indemnización que debería ser procedente tanto si la entidad ha sido o no eximida de constituir caución. Por ello que se echa en falta una previsión por la que esta se produzca, por ejemplo, previendo que ascienda a una cantidad equivalente a la que hubiera sido la caución ${ }^{61}$. judicial que se ven sometidos a la constante aprobación del tribunal de la ejecución". mayor cuando efectivamente se hayan producido daños por importe superior. 
En fin, la revocación habrá de implicar, salvo que se llegue a un convenio en los términos del art. 459 ACPC, el nombramiento de otra persona o entidad especializada.

\section{REFLEXIÓN ÚLTIMA DE CARÁCTER GENERAL}

Al margen de la escasa originalidad de la regulación contenida en los arts. 459 y 460 ACPC, sin duda mejorable por la forma y hasta en cierta medida en algunos aspectos puntuales del fondo, el sistema de la realización contemplado en el ACPC destaca y es novedad precisamente porque la realización por persona o entidad especializada se acordará cuando falte acuerdo entre ejecutante y ejecutado. Esto implica que los medios tradicionales, y principalmente la subasta judicial, son sustituidos por el convenio de realización y, en su ausencia, por la realización por persona o entidad especializada.

Ciertamente la realización está constantemente sometida al acuerdo o a la aprobación judicial ${ }^{62}$. Sin embargo, sin perjuicio de que no implique una verdadera "desjudicialización" sino una delegación de actuaciones concretas cuya adecuación legal ha de ser constantemente verificada por el órgano jurisdiccional, la realización de bienes en el mejor de los casos se extrae del ámbito del "Poder Judicial" cuando no se privatiza. De ese modo, el "Poder Judicial-Estado" en cierto modo se "desvincula" de garantizar que siempre y sin excepciones las personas cuenten con un mecanismo para la realización de los bienes del ejecutado.

Desde muy temprano el Tribunal Constitucional español ha reconocido que el derecho a que una sentencia se cumpla y a que el favorecido por la misma sea repuesto en su derecho o compensado por los daños y perjuicios forma parte del derecho a la tutela judicial efectiva ${ }^{63}$. Derecho que forma parte del ordenamiento jurídico chileno, aunque la Constitución Política no lo contemple expresamente, a través de los tratados internacionales ratificados por Chile ${ }^{64}$. Asimismo, el art. 76 (antes de la reforma art.

62 Así, el acuerdo para que se produzca la comparecencia (inciso segundo art. 459 ACPC), la aprobación judicial del acuerdo (incisos cuarto y quinto del mismo art. 459), el acuerdo de realización por persona o entidad (incisos primero y segundo del art. 460 ACPC), la resolución sobre el resultado de la comparecencia (inciso sexto del mismo art. 460), la aprobación de la realización si ha sido consumada (inciso séptimo), y la resolución revocando el encargo (incisos octavo y noveno).

63 Véase una detallada referencia de la doctrina constitucional española sobre este punto en ORtells Ramos, M. y otros (2005) Derecbo Procesal Civil. Cizur Menor: Thomson-Aranzadi, pp. 672-4.

64 Indica Nogueira Alcalá, Humberto (2003) "Los derechos esenciales o humanos contenidos en los tratados internacionales y su ubicación en el ordenamiento jurídico nacional: doctrina y jurisprudencia". Revista Ius et Praxis, vol. 9, núm. 1, p. 423 (pp. 291-580), en bttp://redalyc.uaemex. $m x /$ redalyc/pdf/197/19790125.pdf, que los derechos contenidos en los 
73) de la misma Constitución Política de Chile reconoce expresamente que "la facultad de conocer las causas civiles y criminales, de resolverlas y de hacer ejecutar lo juzgado, pertenece exclusivamente a los tribunales establecidos por la ley". En mi opinión, ni el derecho a la tutela judicial efectiva ni la atribución exclusiva de la función jurisdiccional para resolver las causas y "hacer ejecutar lo juzgado", impiden per se el sistema de realización forzosa previsto en el ACPC, sin embargo, sí impone al Estado algunos condicionamientos por los que quede garantizado el derecho a la tutela judicial efectiva en el aspecto que de todo ejecutante, sin excepciones, cuente con un mecanismo eficaz de realización.

Por supuesto, no quiere decirse con lo anterior que el mecanismo de realización por último haya de tener un resultado positivo, esto es, una traslación patrimonial a favor del ejecutante. Eso dependerá de cuestiones fácticas diversas: que existan bienes y derechos en el haber del ejecutado, que en los mismos concurran los condicionamientos generales y particulares necesarios conforme a la ley, que tengan un valor patrimonial suficiente y que haya alguna persona dispuesta a su adquisición por este medio. Pero sí impone que quede garantizado que el ejecutante cuente con al menos un medio de realización que permita, si se dan las circunstancias fácticas adecuadas, transformar a dinero los bienes y derechos del ejecutado.

En ese sentido, considero que el sistema diseñado ahora en el ACPC presenta algún déficit. El medio preferente es el convenio de realización, como no podía ser de otro modo en el ámbito de la tutela de los derechos privados, respeto a la autonomía de la voluntad (inciso segundo del art. 1 ACPC) y sometimiento al principio dispositivo (art. 5 ACPC). Sin embargo, al igual que ocurre en el ordenamiento español, se halla condicionado y sometido a la voluntad de los terceros a los que pueda afectar ${ }^{65}$. Como

Tratados internacionales ratificados por Chile, que entran en el derecho interno a través de la previsión del art. 5.2 Constitución Política de Chile. Y todavía más rotundamente, Palomo Vélez, Diego I. (2003) "La anulación de procesos tributarios por parte de la Sala tramitadora de la Corte de Apelaciones de Santiago: Algunas notas en torno al derecho de acceso a la justicia en estas materias". Revista Ius et Praxis, vol. 9, núm. 1, p. 527, en bttp:// redalyc.uaemex. $m x /$ redalyc/pdf/197/19790125.pdf, afirma que "poco relevante resulta que nuestro texto constitucional no haya asegurado expresa y generalmente el derecho de acceso a la jurisdicción, toda vez que se entienden incorporados - con jerarquía constitucional- a nuestro ordenamiento los derechos fundamentales contenidos en los tratados internacionales sobre Derecho Humanos ratificados por Chile y que se encuentran vigente... en otras palabras, nuestro ordenamiento jurídico sí cuenta con normas de jerarquía constitucional que aseguran y reconocen el derecho de acceso a la jurisdicción". Hasta el punto es así que se ha afirmado que la enumeración del art, 19 de la Constitución chilena no es taxativa y ha de entenderse que, como señala Evans dE LA CuAdra, Enrique (1999) Los derechos constitucionales. T. I. Santiago: Editorial Jurídica de Chile, pp. 23-24, citado por Nogueira Alcalá (2003) nota 27 , todos los derechos fundamentales del hombre, estén o no en el texto constitucional, están cautelados por él. 
la existencia de perjuicios a terceros será la nota habitual, la condición impuesta para la aprobación del convenio hará inviable en la práctica la operatividad de este medio de realización. El sistema, de ese modo, queda abocado sin alternativas a la realización mediante persona o entidad especializada.

Y como en lo esencial el art. $460 \mathrm{ACPC}$ se ha limitado a trasladar el correlativo art. $461 \mathrm{LEC}$, pensado en el ordenamiento español como medio alternativo a la subasta judicial y no sustitutivo como el ACPC, nos encontramos ahora con ciertas carencias en cuanto a garantías de la operatividad del sistema en el contexto diseñado por el ACPC. En efecto, el art. 460 ACPC, quizá como consecuencia de una experiencia poco gratificante en el funcionamiento de las subastas judiciales, parece confiar a la iniciativa privada la instrumentación de las infraestructuras necesarias para la operatividad de este medio de realización. Parece olvidarse así que toda actividad mercantil persigue como fin primordial la obtención de (justos) beneficios, no la satisfacción de los derechos fundamentales de las personas. Aunque no se haya de excluir ni desaprovechar que en ocasiones la actividad mercantil pueda de paso dar satisfacciones a estos derechos, corresponde al Estado la garantía y el establecimiento de los medios necesarios para que los derechos fundamentales puedan ejercerse en condiciones de normalidad. Lo bien cierto es que se abandona el ejercicio de un derecho fundamental a la eventual concurrencia de que existan expectativas de negocio, pues es claro que la actividad mercantil se desarrollará solamente en la medida de que existan oportunidades de "negocio". Y posteriormente, una vez constituidas, todavía queda la posibilidad de que ciertas operaciones menos rentables queden relegadas o excluidas por parte de las personas o entidades, en perjuicio del interés particular del ejecutante y del general del pleno ejercicio de los derechos.

En fin, convendría reflexionar sobre estas cuestiones con el objeto de introducir unos mecanismos que garanticen en todos los casos y circunstancias que el ejecutante no va a quedar huérfano de la posibilidad de realización de los bienes y derechos del ejecutado. Al menos, entre otras medidas, previendo que la iniciativa pública garantice, con independencia de las posibilidades de negocio, el ejercicio en este ámbito del derecho a la tutela judicial efectiva.

midad de los sujetos a quienes afectare (cuando se trate de bienes susceptibles de inscripción registral, acreedores y terceros poseedores que hubieran inscrito o anotado sus derechos con posterioridad al gravamen). 


\section{BiBLIOGRAFÍA}

- Banacloche Palao, Julio (2001) "Del convenio de realización", Comentarios a la Ley de Enjuiciamiento Civil (con De la Oliva, Díez-Picazo y Vegas). Madrid: Civitas.

- Bonet Navarro, José (2002) "Alternativas a la subasta en el proceso civil de ejecución”, Revista Internauta de Práctica Jurídica, núm. 10, en http://www.uv.es/ ripj/10alt.htm

- Casero Linares, Luis (2001) "Procedimiento de apremio". Garbería (Coordinador) Los procesos civiles. Comentarios a la Ley de Enjuiciamiento Civil, con formularios y jurisprudencia, 5. Barcelona: Bosch.

- Cordón Moreno, Faustino (2001a) "Del convenio de realización". En Cordón, Armenta, Muerza y Tapia (coor.). Comentarios a la Ley de Enjuiciamiento Civil, II. Elcano: Aranzadi.

(2001b) "Realización por persona o entidad especializada". En Cordón, Armenta, Muerza y Tapia (coor.). Comentarios a la Ley de Enjuiciamiento Civil, II. Elcano: Aranzadi.

- Evans de la Cuadra, Enrique (1999) Los derechos constitucionales. T. I. Santiago: Edicorial Jurídica de Chile.

- Fernández Seijo, José María "La ejecución en la nueva Ley de Enjuiciamiento Civil". En http://perso.wanadoo.es/ilandin/textos/librotercero.html

- Franco Arias, Just (2000) "Del convenio de realización". En Lorca (Director) Comentarios a la nueva Ley de Enjuiciamiento Civil, III, Valladolid: Lex Nova.

- Hoya Coromina, José (2000) "Del convenio de realización”. En Fernández-Ballesteros, Rifá y Valls (Coordinación) Comentarios a la nueva Ley de Enjuiciamiento Civil. Artículos 556 al 827. Barcelona: Iurgium editores.

- Montero Aroca, Juan (2001) El nuevo proceso civil. Ley 1/2000 (con Gómez, Montón y Barona). Valencia: Tirant lo Blanch, $2^{\mathrm{a}}$ ed.

- Moreno Catena, Víctor (2000) "La ejecución forzosa". En Moreno y Cortés (Coordinadores) La nueva Ley de Enjuiciamiento Civil, IV. Madrid: Tecnos.

- Nogueira Alcalá, Humberto (2003) "Los derechos esenciales o humanos contenidos en los tratados internacionales y su ubicación en el ordenamiento jurídico nacional: doctrina y jurisprudencia". Revista Ius et Praxis, vol. 9, núm. 1, en http://redalyc.uaemex.mx/redalyc/ pdf/197/19790125.pdf

- Ortells Ramos, M. y otros (2005) Derecho Procesal Civil. Cizur Menor: Thomson-Aranzadi.

- Palomo Vélez, Diego I. (2003) "La anulación de procesos tributarios por parte de la Sala tramitadora de la Corte de apelaciones de Santiago: Algunas notas en torno al derecho de acceso a la justicia en 
estas materias”. Revista Ius et Praxis, vol. 9, núm. 1, en http://redalyc. uaemex.mx/redalyc/pdf/197/19790125.pdf

- Pedraz Penalva, Ernesto / Moral Moro, María José (2001) “El procedimiento de apremio". En Gimeno (Director) Proceso Civil Práctico, VIII-1. Madrid: La Ley.

- Redondo García, Fernando (2000) "Líneas generales del procedimiento de apremio". En Alonso-Cuevillas (Coord.) Instituciones del Nuevo Proceso civil. Comentarios sistemáticos a la Ley 1/2000, III. Barcelona, Economist\&Jurist.

- Robledo Villar, Antonio (2001) "La realización forzosa de bienes en la Ley de Enjuiciamiento Civil a través de los medios alternativos a la subasta judicial”. En Robledo y otros. Estudios jurídicos, secretarios judiciales, VII-2001. Madrid, Centro de Estudios Jurídicos de la Administración de Justicia.

- Rodríguez Ruiz de Villa, Daniel (1998) "Reflexiones sobre el avalúo y la subasta de inmuebles en el Anteproyecto de Ley de Enjuiciamiento Civil". La Ley, 4.

- Vegas Torres, Jaime (2000) Derecho Procesal Civil. Ejecución forzosa. Procesos especiales (con De la Oliva y Díez-Picazo). Madrid: Editorial Centro de Estudios Ramón Areces. 